NBER WORKING PAPER SERIES

PROPERTY RIGHTS AND FINANCE

\author{
Simon Johnson \\ John McMillan \\ Christopher Woodruff
}

Working Paper 8852

http://www.nber.org/papers/w8852

\author{
NATIONAL BUREAU OF ECONOMIC RESEARCH \\ 1050 Massachusetts Avenue \\ Cambridge, MA 02138 \\ March 2002
}

The views expressed herein are those of the authors and not necessarily those of the National Bureau of Economic Research.

(C) 2002 by Simon Johnson, John McMillan and Christopher Woodruff. All rights reserved. Short sections of text, not to exceed two paragraphs, may be quoted without explicit permission provided that full credit, including (C) notice, is given to the source. 
Property Rights and Finance

Simon Johnson, John McMillan and Christopher Woodruff

NBER Working Paper No. 8852

March 2002

JEL No. D23, P23

\begin{abstract}
Which is the tighter constraint on private sector investment: weak property rights or limited access to external finance? From a survey of new firms in post-communist countries, we find that weak property rights discourage firms from reinvesting their profits, even when bank loans are available. Where property rights are relatively strong, firms reinvest their profits; where they are relatively weak, entrepreneurs do not want to invest from retained earnings.
\end{abstract}

Simon Johnson

Sloan School of Management

MIT

50 Memorial Drive, E52-562

Cambridge, MA 02142-1347

and NBER

sjohnson@mit.edu
John McMillan

Christopher Woodruff 


\section{Property Rights and Finance}

\section{Simon Johnson, John McMillan, and Christopher Woodruff*}

Which is the tighter constraint on private sector investment: weak property rights or limited access to external finance? From a survey of new firms in post-communist countries, we find that weak property rights discourage firms from reinvesting their profits, even when bank loans are available. Where property rights are relatively strong, firms reinvest their profits; where they are relatively weak, entrepreneurs do not want to invest from retained earnings. (JEL D23, P23)

Property rights are fundamental: entrepreneurs will not invest if they expect to be unable to keep the fruits of their investment. Country-level studies consistently show that less secure property rights are correlated with lower aggregate investment and slower economic growth (Stephen Knack and Philip Keefer, 1995; Paolo Mauro, 1995; Jakob Svensson, 1998; Daron Acemoglu, Johnson and James Robinson, 2001). The microeconomic evidence is more limited, but Timothy Besley (1995), for example, finds in Ghana a significant link between property rights and investment.

Secure property rights may be necessary for entrepreneurial investment, but are they sufficient? External finance could also matter for investment and growth, for if bank credit is not available it may be hard for entrepreneurs to take advantage of new opportunities. There is evidence that a well-functioning financial system contributes to 
investment and growth (Ross Levine, 1997; Raghuram Rajan and Luigi Zingales, 1998). Is external finance, in addition to secure property rights, necessary for entrepreneurs to invest, or is property-rights security all that is needed? Broad cross-country studies cannot answer this question because effective protection for property rights is positively correlated with the use of external finance. For example, Rafael La Porta, Florencio Lopez-de-Silanes, Andrei Shleifer and Robert W. Vishny $(1997,1998,2000)$ show more external finance is available when there is a stronger legal system in general and more effective protection of investors in particular, while Asli Demirgüç-Kunt and Vojislav Maksimovic (1998) find that firms invest more from external funds in countries with secure property rights.

Recent experience in Eastern Europe and the former Soviet Union offers an experiment that can help disentangle the effects of property rights and external finance. Although all these former communist countries have relatively weak institutional environments, there is considerable variation in the extent to which property rights are protected. For example, Timothy Frye and Shleifer (1997) and Shleifer (1997) provide evidence that the Russian government acts like a "grabbing hand," discouraging entrepreneurs from investing, while the Polish government does not. In general, property rights have proven more secure in Poland than in other parts of Eastern Europe and the former Soviet Union. Within countries, also, there is variation in both the perceived security of property rights and in the access to bank credit. Given these countries' banking systems, small firms are able to borrow only if they can provide adequate collateral. Owning collateral is therefore a good proxy for at least having the possibility to borrow. Firm-level evidence from these post-communist countries therefore allows us 
to determine whether secure property rights are (a) necessary, (b) sufficient, or (c) necessary and sufficient for investment by entrepreneurs.

Our data come from a 1997 survey of recently formed and relatively small manufacturing firms in five transition countries: Poland, Romania, Slovakia, Ukraine, and Russia. The perceived security of property rights and the use of bank credit vary considerably both across and within these countries. As an outcome variable, we focus on the amount entrepreneurs choose to reinvest out of their profits. This provides a robust measure of investment, as our survey work indicates, that is comparable across firms.

Our approach has two parts, both of which are designed to be straightforward to implement in countries where standard financial information is hard to obtain. First, we explain the data we were able to obtain, putting particular emphasis on what our investigation shows is a reasonable way to ask questions about sensitive financial information and property rights issues (Section I). ${ }^{1}$ Second, we test whether secure property rights are sufficient for investment by entrepreneurs (Sections II and III).

The entrepreneurs in our sample reinvest less of their retained earnings when they perceive their property rights to be insecure, irrespective of whether they own the collateral that is generally needed to obtain credit. This effect is large. Those entrepreneurs in our sample with the least secure property rights invest nearly 40 percent less of their profits than those with the most secure property rights (specifically, entrepreneurs with the least secure perceived property rights reinvest 32 percent of their profits, while those with the most secure reinvest 56 percent). Secure property rights are necessary for the entrepreneurs in our sample to take full advantage of opportunities to 
invest. Moreover, we find that the absence of bank finance does not prevent the entrepreneurs in our sample from investing. Controlling for property rights, there is no evidence that access to bank credit leads to more investment for these firms. Secure property rights are therefore also sufficient for investment. In fact, the firms in our sample with weak perceived property rights and high levels of unreinvested profits do not want to borrow.

Part of the explanation for these results is that, for the firms in our sample, retained earnings have consistently been large, and therefore have been a source of potential investment funds. Many of these new firms are extremely profitable because the relatively hostile business environment creates barriers to entry and because the partially reformed economy offers entrepreneurs lucrative unfilled niches. ${ }^{2}$ High profits mean that entrepreneurs have the resources they need for expansion, without needing to borrow. The issue is not whether entrepreneurs have enough resources, but rather whether they want to invest their retained earnings or instead consume these earnings, perhaps outside the country.

At the low level of institutional development of the countries in our sample, secure property rights are both necessary and sufficient to induce investment by entrepreneurs. The availability of bank loans surely matters for growth, but perhaps only once property rights are perceived to be secure. If property rights are insecure, it is immaterial whether or not finance is available. Our findings thus add empirical detail to the view that certain market-supporting institutions will work only after other institutions have been built (McMillan, 1997; Shleifer and Vishny, 1998). 
Because our survey covers only firms already in existence, we cannot infer anything about the relative importance of property rights and finance for potential entrepreneurs who are considering entry. We focus instead on entrepreneurs who are already in business with small-scale operations. Our question is: under what conditions will these entrepreneurs reinvest their profits to make their businesses grow?

\section{The Data}

\section{The Sample}

We surveyed private manufacturing firms in May and June of 1997 in Russia and Ukraine and from September to December of 1997 in Poland, Slovakia, and Romania. ${ }^{3}$ The survey was designed to find similar relatively small firms in comparable cities in all five countries.

We chose the countries explicitly to look for variation in institutional conditions. The previously available cross-country evidence, for example from European Bank for Reconstruction and Development (EBRD, 1996) and Shleifer (1997), suggested that property rights were less secure in countries further to the East. We intentionally surveyed only firms that were going concerns, in order to focus on investment decisions by firms that had managed to enter an industry and survive. Other researchers have found that weak property rights increase barriers to entry (Simeon Djankov, La Porta, Lopez-de-Silanes, and Shleifer 2000). Daniel Berkowitz and David N. DeJong (2000)

find variation across Russian regions in the rate of formation of new firms is associated with the degree of local political support for reform. This paper looks instead at the 
effects of weak property rights on entrepreneurial investment conditional on entry having occurred.

The sample includes about 300 manufacturing firms with between seven and 270 employees in each country; the total sample size for most variables is about 1400

observations. Some of the firms were started from scratch and others were spun off from state enterprises, which probably reflects characteristics of the population of firms. In our sample for Poland, Romania and Slovakia, startups far outnumber spinoffs; in Russia and especially Ukraine, spinoffs predominate. We control for these characteristics of the firms in our regression analysis.

\section{The Questions}

The survey design incorporated both experience of previous surveys on these topics and the results of pilot studies we carried out in each country. The pilots tested precisely how people understood various questions and established the best ways to ask about sensitive information. For the purposes of this paper, the most important issue was how to ask about profits and their reinvestment.

We expected respondents would be reluctant to answer questions about the specific nominal amounts of profits and investments, and we found this to be the case. However, they were more willing to answer questions posed in terms of ratios. We also found that respondents found it much easier to answer questions that posed this ratio in terms of a closed-end question listing various ranges from which they could choose. For example, our key question was: "How much did you re-invest out of profits during 1996?" We offered respondents six choices: 0 percent, 1-10 percent, 11-25 percent, 26- 
49 percent, 50-75 percent, or more than 75 percent. Both the use of ratios and the closed categories represent compromises. We obtain much higher response rates: in the case of reinvestment rates, the response rate exceeded 94 percent. ${ }^{4}$ But we have only categorical rather than continuous data. As a result, our regressions will be ordered probits.

Previous research indicated that for particularly sensitive issues, for example relating to bribes and other issues linked to security rights, the response rate was higher when we posed the questions in terms of asking about "firms in your industry" rather than the entrepreneur's own firm. ${ }^{5}$ Our assumption, based on other experience, is that answers to this question reflect the entrepreneur's own experience. At least one respondent confirmed this, telling our survey firm that he knew the questions were designed to "disguise the fact that [the survey] was after information about his own firm." He responded to the questions anyway.

\section{Measuring Property Rights}

The entrepreneur's beliefs about the security of his or her property rights are indicated by responses to several survey questions. We asked entrepreneurs first whether firms in their industry make "extralegal payments" for government services, and second whether firms in their industry make "extralegal payments" for licenses. More than 90 percent of the Russian entrepreneurs and almost 90 percent of Ukrainian entrepreneurs answered affirmatively to these questions (see the first two rows of Table 1). Only one in five entrepreneurs in Poland and Romania said firms make extralegal payments for services or licenses. The response rates for these questions are well above 98 percent in the three Eastern European countries, but are 40 percent or less in Russia and Ukraine. One reasonable interpretation of a refusal to answer the question, in this context, is that 
the entrepreneur makes these payments and - for obvious reasons - does not want to discuss them.

We also asked whether firms make payments for "protection" of their activities, finding a similar pattern of responses across the countries (in the third row of Table 1). We chose not to ask directly about whether firms made payments to organized crime, because we expected that most entrepreneurs would not admit this. However, the indirect question probably picks up whether a firm believes it is likely to be subject to extortion by some form of mafia - although we would caution that anecdotal evidence suggests this sort of organized crime often operates with the tacit protection of some local government officials.

For further measures of property-rights security, we asked entrepreneurs whether they make "unofficial" payments for specific services: payments for renewing their business registration, and payments to fire, sanitary, and tax inspectors (see the fourth, fifth, and sixth rows of Table 1). Though the response rates to these questions are lower, the pattern is the same. A majority of entrepreneurs in Russia and Ukraine say such payments are common, while a minority of entrepreneurs in the other three countries says the same. We use these detailed corruption measures to check the robustness of results from our basic regression.

Official payments to government are also higher in Russia and Ukraine, where tax payments are more than one quarter of sales, compared to about a sixth of sales in Eastern Europe (see the seventh row of Table 1). ${ }^{6}$ We control for tax payments as a percent of sales to see whether this is a direct disincentive to invest. We do find some 
evidence that investment rates are negatively impacted by higher tax rates, though in contrast to other results, the tax rate findings are not robust.

Using courts to enforce contracts with trading partners is a logically distinct activity from protecting property rights. Nevertheless the effects on investment are similar. Inadequate contractual enforcement could put firms' profits at risk and make them reluctant to invest. Asked whether courts could be used to enforce an agreement with a customer or supplier, most firms in all of the countries said they could. Affirmative answers to this question ranged from 87 percent in Romania to 56 percent in Ukraine (see the last row of responses in Table 1).

Overall, Table 1 shows that the five countries fall into two distinct groups - the three East European countries have relatively more secure property rights than do the two former Soviet Union countries. Courts are less reliable in resolving commercial disputes in Russia and Ukraine, and interactions with the government are also more costly in these countries. This is consistent with the existing evidence that the regulatory environment in Eastern Europe is less hostile to business activity than in the former Soviet Union (see, for example, Frye and Shleifer, 1997).

Entrepreneurs' perceptions of the security of property rights may vary within a country for three reasons. First, different firms may face different realities. Interaction with the government may be more frequent in some industries than in others. Activities may vary in the ease with which they can be hidden from government bureaucrats. And some entrepreneurs may have connections that allow them to avoid extortion. In our data, for example, entrepreneurs who previously worked as high-level entrepreneurs in state owned enterprises are less likely to say bribes are paid. Second, entrepreneurs may differ 
in their perceptions. This is especially likely in an economy undergoing deep reform, where institutions and circumstances change quickly. We find, for instance, that older entrepreneurs are less likely to say bribes are paid. Third, the responses may reflect some other characteristic of the firm or the entrepreneur. In our regressions we control for as many characteristics as possible, but some unobserved attributes may matter for investment.

\section{An Index of the Insecurity of Property Rights}

Table 2 shows the correlations among our property-rights measures for individual firms in all five countries. Not surprisingly, most are highly correlated. Extralegal payments for services and extralegal payments for licenses have a correlation coefficient of 0.66 , while the correlation between payments for "protection" and either of these measures is larger than 0.50 .

For our regression analysis, we combine the three main property-rights questions — extralegal payments for licenses, extralegal payments for services, and paying for protection — into an additive index of property-rights insecurity for each firm. The property-rights index we construct ranges from 0 to 3 , with 3 indicating that the entrepreneurs said all three payments were common, 2 indicating an affirmative response to two of the payments, 1 indicating an affirmative response to one of the payments, and 0 indicating an affirmative response to none. A higher value of this index therefore represents less secure property rights. 
An alternative index for property rights insecurity would equal one if firms make any one of the three types of payments and zero otherwise. Either of these indexes can be justified theoretically.

The additive index is appropriate if responding affirmatively to more than one question indicates a greater level of insecurity than responding affirmatively to only one question. The either/or index is appropriate if one bribe-taker has the same effect as multiple bribe-takers. According to the model of Shleifer and Vishny (1993), if two or more corrupt bureaucrats coordinate so as to maximize their total bribes, they will extract the same total amount as a monopoly extortionist. If they compete with each other, however, their total bribes will, by prisoners'-dilemma logic, exceed the bribemaximizing amount. The data show the effects of corruption are additive, as discussed below (Section III), suggesting the rate of total bribes might exceed what even the bribetakers would want.

A belief that courts are not effective in enforcing contracts is positively correlated with the corruption measures, but the correlation is smaller. The correlation between courts and the index for insecurity of property rights is 0.15 . While this correlation may seem low, it probably reflects the fact that believing the courts can enforce private contracts is quite different from trusting the government not to expropriate your property. With regard to courts, the issue is presumably whether judges are incompetent or corruptible. With regard to security of property rights, the issue is to what extent members of the executive feel constrained to act responsibly and within the law. Even in environments where the executive is quite predatory (Russia, for example), we see 
considerable willingness on the part of entrepreneurs to rely on courts for the enforcement of contracts with other entrepreneurs.

In the main regressions, we use the effectiveness of courts alongside the index of property rights. We also run regressions using the components of the index separately. Finally, an alternative index of property rights that we use in the regressions, ranging from 0 to 4, adds to the first index the measure of the ineffectiveness of courts (that is, we add one if the entrepreneur thinks the courts cannot be used to enforce contracts and zero otherwise).

\section{Reinvestment of Profits}

Initial entrants in transition economies often earn large profits, which decline over time as new firms enter (McMillan, 1997). Our data are consistent with this at the country level. Table 3 (second line) shows the firms' average profit after taxes as a percent of sales in 1996. Reported after-tax profits are much higher in Russia (21 percent) and Ukraine (18 percent), where there has been the least progress with economic reform, than in Poland (10 percent), where the transition has progressed much further. Romania is in between (13 percent). Slovakia appears to be the outlier in this pattern, with profit rates much lower than in any of the other countries ( 6 percent $){ }^{7}$ Entrepreneurs were also asked to estimate profit rates after taxes in their industry, as a percent of sales. As we would expect, the estimates of industry profits and the firm's own profit rates are highly correlated $(?=0.41)$. At the country level, these estimates, also shown in Table 3 (third line), indicate a similar pattern, but with less variation across countries. ${ }^{8}$ 
These profit rates are high relative to the available data for large firms in these countries. The best data are for Poland. According to the most recent data in Worldscope, average profit/sales for Polish firms from all industries is about 5 percent. ${ }^{9}$ However, this average hides considerable disparity. In particular, large firms operating in sectors with substantial barriers to entry, for example due to regulations, had sales-profit ratios that were comparable to the small firms in our sample.

These data are consistent with the idea that the insecurity of property rights may deter entry into the small firm sector (Djankov, La Porta, Lopez-de-Silanes, and Shleifer, 2000). In addition, these partially reformed post-communist economies offer entrepreneurs lucrative unfilled niches. There is also presumably a survivorship bias for small firms. We are measuring only the firms that have not gone out of business (although arguably this should overstate the importance of external finance and understate the importance of expropriation risk). Large firms may not show such a bias because, in these countries, the government may provide implicit subsidies that prevent them from going out of business.

Entrepreneurs also reported profits as a percentage of sales during their firm's first full year of operation. We show in Table 3 (see the sixth, seventh, and eighth lines) the average first year profit rates by country and by year in which the firms began operation. In Poland, firms started between 1989 and 1991, just after the reforms, reported earning an average of 9.9 percent of sales during their first year of operation. First year profits were markedly lower - 4.2 percent of sales - for firms started in 1992 or 1993, and lower still for the most recent group of entrants (2.1 percent of sales for firms 
entering between 1994 and 1996). These data are consistent with our expectation that entry leads to lower profit rates.

A downward trend over time in profit rates for entrants in their first year of business is also evident in Slovakia and Romania, though the rate of fall is not as steep as in Poland. There is even less difference across time in the profit rates of startup firms in either Russia or Ukraine. Firms entering between 1989 and 1991 had average first year profit rates of 4.3 percent and 7.6 percent of sales in Russia and Ukraine, respectively. Those entering five years later had average profit rates of 3.9 percent and 7.4 percent of sales, respectively. ${ }^{10}$

We also asked what fraction of 1996 profits after taxes were reinvested in the firm. Polish and Romanian firms reinvested the highest fraction, slightly more than 50 percent on average (fourth line of Table 3). Reinvestment rates average about 40 percent in Slovakia and Russia, and 30 percent in Ukraine. ${ }^{11}$ We also compute the profits entrepreneurs choose not to reinvest in their businesses (fifth line of Table 3). Unreinvested profits as a percentage of sales are highest in Russia and Ukraine, where they exceed 10 percent of sales, and lower in Romania (5.9 percent of sales), Poland (5.2 percent) and Slovakia (5.1 percent). In Russia and Ukraine, where property rights are the least secure, entrepreneurs are on average the most reluctant to reinvest their profits.

Table 3 also divides these data into startups and spinoffs. Startups are more profitable than spinoffs in all five countries, though the difference is much greater in Poland and Romania than in the other three countries. Startups reinvest a greater proportion of their profits than spinoffs in Poland, Slovakia and Romania. 


\section{External Finance}

The survey contains three indications of having received bank credit. First, we asked firms what their sources of startup capital were. A minority of firms, ranging from 6.6 percent of Polish firms to 27 percent of Slovakian firms, obtained part of their startup capital from bank loans (see the second line of Table 4). Second, we asked whether they obtained a loan at some point in the past. Over 90 percent of Russian firms and 79 percent of Ukrainian firms say they have received loans at some time (third line of Table 4). Only half of Slovakian and Romanian firms have had a loan at some point in the life of the enterprise. Third, we asked whether they obtained loans from banks in 1996, the year before the survey. The greatest percentage of current borrowers was in Poland, where just under half (49 percent) of firms said they had loans in 1996. About a quarter of firms in Slovakia and Romania said they had loans in 1996, with lower percentages in Russia (17 percent) and Ukraine (14 percent). ${ }^{12}$

Although fewer firms in Russia and Ukraine received loans than in the other three countries, the average loan size was larger there. Loans average less than 5 percent of a borrower's annual sales in Poland, more than 10 percent of annual sales in Slovakia and Ukraine, and almost 25 percent of annual sales in Russia. As a result, the variation across countries in the total funds provided by banks is small. Including firms who do not receive loans, Slovakian firms received the most credit in 1996, amounting to 2.5 percent of annual sales. In Poland and Russia, finance provided by banks represents 2.3 percent of annual sales, in Romania 1.7 percent and in Ukraine 0.8 percent.

Even though Polish firms are much more likely to have obtained a loan in 1996 than firms in the other four countries, the Polish credit markets are underdeveloped by 
western standards. In the United States, small and medium sized firms are surveyed periodically by the Federal Reserve Board of Governors (FRBG). Among the 344 firms in the 1993 National Survey of Small Business Finances (NSSBF) that are manufacturers with between 10 and 270 employees, 84 percent reported having a loan at the time of the survey. This level is substantially higher than the 49 percent rate in Poland. Moreover, loan amounts were 16 percent of sales among the group of small US manufacturers, several times the levels in any of the countries we surveyed..$^{13}$

Compared to a developed capital market, loans in our five countries are also much more likely to require collateral. While 20 percent of bank loans obtained by US firms were without collateral, less than 2 percent of the firms in our sample obtaining loans did so without collateral. A lack of collateral, however, is not the main reason for less borrowing in our sample than in the US. More than 75 percent of firms in each of the countries - and more than 90 percent of firms in Poland and Romania - say they were able to offer collateral to banks. At least in the minds of entrepreneurs, a lack of collateral does not appear to be a major constraint on borrowing. ${ }^{14}$

An alternative source of external funds is credit received from other firms. We measure trade credit by the level of accounts payable reported by firms (the eighth and ninth rows of Table 4). Trade credit is almost non-existent in Russia ( 0.1 percent of annual sales) and is low in Ukraine (0.7 percent), but is an important source of capital in Poland (2.7 percent) and Slovakia (3.4 percent). Credit received from suppliers is comparable in size to credit received from banks in Poland, Slovakia and Ukraine. Reliable data for this question are not available for Romania. ${ }^{15}$ (For more on trade credit, 
see Johnson, McMillan, and Woodruff (2000), where we use trade credit as a measure of a firm's trust in its trading partner.)

Profit reinvestment is a larger source of investment capital than either bank funds or trade credit in all five countries, as is seen by comparing Tables 3 and 4 (except that trade credit is bigger than profit reinvestment in Slovakia). In Poland, firms internally generate funds for investment averaging 53 percent of sales (Table 3, fourth line). Bank loans average 2.3 percent of sales for the whole sample and 4.8 percent of sales for firms receiving loans in Poland (Table 4, sixth and seventh lines). In contrast, we estimate that firms in Russia and Ukraine have unreinvested profits averaging 12 percent of sales (Table 3, fifth line). This suggests the Russian and Ukrainian firms could have used their unreinvested profits in productive projects (earning high rates of return), but for some reason they chose not to. The potential for using retained earnings as a source of capital is seen from the fact that in, all five countries, the capital available from unreinvested profits exceeds the capital provided by banks (compare the fifth row in Table 3 with the sixth row in Table 4).

Table 2 shows correlations between the various measures of property rights on the one hand and variables indicating access to credit on the other. We would be concerned if access to capital is strongly correlated with security of property rights, because that would make it difficult to disentangle access to credit from security of property. We measure the ability to access credit in 1996 with two variables - an indication that the firm received a bank loan at some point before 1996, and an indication that the firm has collateral that can be used to obtain a loan. The correlations indicate that firms with less secure property rights are more likely to have had a loan before 1996. Firms with less 
secure property rights are less likely to have collateral to offer banks, but the correlation is small and is significant only for the index of insecurity and for a lack of confidence in courts. Hence, we are not concerned that our measures of insecure property rights are proxying for a lack of access to credit. ${ }^{16}$

\section{Assessment}

The cross-country evidence suggests that property rights are an important determinant of investment by entrepreneurs. In Poland, where property rights are relatively secure, we find high rates of reinvestment. In contrast, in Russia and Ukraine, where property rights are weak, we find that the level of unreinvested profits is high; entrepreneurs there have the ability to do much more investment than they actually do. The next question is whether these results hold in the firm-level data when we control for characteristics of the firm and entrepreneur.

\section{A Framework for Investment Decisions}

This section lays out a simple framework that explains and defends the assumptions needed for our regression analy sis. A firm's desired investment level is a function of both industry and firm-specific factors. Firms in growing industries are faced with more investment opportunities than are firms in declining industries. Production in a capital-intensive industry also necessitates higher investment levels. More able entrepreneurs will find investments more profitable in any industry. All of these factors affect the profitability of potential investments. 
Investment demand also depends on the ability of entrepreneurs to retain any profits they make. Entrepreneurs may be unwilling to invest when returns are insecure. The effect of entrepreneurs' perceptions of property rights on investment decisions is the main issue we want to explore. Suppose that the firm makes its investment and borrowing decisions simultaneously, and extortion, if it occurs, comes after any profits are realized, so that firm's demand for investable funds is given by

$$
I^{d}=I\left(p, s, r^{I}, r^{L}\right),
$$

where $p$ represents expected (pre-extortion) profits, s represents the amount of those profits that will be extracted by corrupt bureaucrats or criminals, $r^{I}$ represents the interest rate the entrepreneur can earn by investing the firm's profits outside the firm and $r^{L}$ the interest rate the entrepreneur pays on borrowed money. Investable funds may be obtained either internally from retained earnings or externally through credit markets. Thus:

$$
I^{d}=R+L^{d},
$$

where $R$ represents reinvested earnings and $L^{d}$ is the firm's demand for loans.

The usual assumption is that the value to the firm of internal funds, $r^{I}$ is less than the cost to the firm of external funds, $r^{L}$. The wedge between the two interest rates arises because entrepreneurs have better information about their prospects than outside lenders or investors. Lenders demand a premium to offset their informational disadvantage. The difference between $r^{I}$ and $r^{L}$ creates a pecking order in which internal funds are exhausted first before external funds are obtained (Stewart C. Myers and Nicholas S. Majluf 1984, Lakshmi Shyam-Sunder and Myers 1999). This idea was developed from the experience of firms in the United States. The wedge between the value of internal funds and the cost 
of external funds is likely to be larger in transition countries than in developed market economies because information sources are missing and investment uncertainties are much greater in transition countries. Information asymmetries are therefore likely to be more severe.

Firms in transition economies have another reason to prefer internal financing in addition to borrower/lender information asymmetries. External financing makes it hard for firms to hide their activities from tax collectors or the mafia. The effective cost of external finance in Russia is increased, according to Anna Meyendorff (1998), by the fact that firms that apply for a bank loan are more likely to have to pay their taxes. According to Richard Lotspeich (1996), firms are reluctant to disclose information to banks for fear it will be leaked to the mafia. Given these conditions, the assumption that the value of internal funds is less than the cost of external funds is a reasonable one to make in examining the investment decisions of firms.

The difference in cost of internal and external funds leads to a discontinuity between the investment of internal funds and the decision to seek external funds. Investment projects must have an expected return (after extortion and adjusted for risk) comparable to $r^{I}$ to be profitable when financed by internal funds, but a return comparable to $r^{L}$ to be profitable when financed by external funds. As a result, a firm's decision to invest internally generated funds is made independently of a decision to seek external finance. This allows us to estimate econometrically an equation for reinvestment of profits independent of the demand for external finance.

We represent the pecking-order hypothesis by supposing that firm i has a maximum amount of money that it is willing to reinvest out of its current profits, $E_{i}$; this 
might be the total current profit, or it might be strictly less than that. We assume $E_{i}$ depends on entrepreneur-specific characteristics. Then the pecking-order hypothesis implies:

$$
\begin{array}{ll}
I^{d}=R, & \text { if } I^{d} \leq E_{i} \\
I^{d}=E_{i}+L^{d}, & \text { if } I^{d}>E_{i}
\end{array}
$$

This gives us the main equation we will estimate, relating the firm's willingness to reinvest its profits to its expected profits and the security of its property rights:

$$
\begin{array}{ll}
R=I\left(p, s, r^{I}\right), & \text { if } I^{d} \leq E_{i} \\
R=E_{i}, & \text { if } I^{d}>E_{i} .
\end{array}
$$

In our data, we will use explicit measures of $p$ and $s$. Differences in $r^{I}$ across firms in the sample will be subsumed in country/industry control variables.

If the assumption that investment of internally generated funds is independent of access to external funds were invalid, then investment of internal and external funds would need to be examined simultaneously. There are (at least) three reasons that investment of internal funds might depend on access to external funds. First, $r^{L}$ may not be higher than $r^{I}$ if loans are subsidized by the government. This does not appear to be the case in our data. Subsidies were most important in loans to state-owned firms. There are no state-owned firms in our sample. Only in Romania do we find that interest rates paid by firms spun off from state-owned enterprises are lower than those paid by de novo startups. In the remaining countries, there are no significant differences in loan rates between the two groups of firms. Moreover, across the sample, loans given by state banks have higher interest rates than loans given by private banks. In Poland and Slovakia, 
where loans are equally divided between state and private banks, interest rates are nearly the same, with rates from state banks very slightly higher than rates from private banks.

Second, entrepreneurs for whom property rights are insecure may prefer to invest bank funds in their businesses and to divert internally generated funds to more secure accounts. This implies that firms receiving loans should invest, on average, a lower proportion of their own profits than firms without loans. The data suggest this is not the case. Among the most profitable firms (those with profits 10 percent or more of sales) who are investing less than half of their profits, loans are infrequent. Only 64 of 476 (13 percent) of these firms received loans in 1996. On the other hand, 104 of the 259 (40 percent) firms investing more than 75 percent of their profits received loans. ${ }^{17}$ The survey does not indicate whether a loan received in 1996 represented new capital, or a rollover of a loan from previous years. But we would expect that firms investing most of their profits are both more likely to rollover existing loans and more likely to take out new loans. In either case, firms that are investing aggressively will be more likely to have a loan in 1996 , as the data suggest.

Finally, investment may be lumpy, with the minimal investment larger than retained earnings can accommodate. Given the level of technology used by small-scale manufacturers in these countries, however, it seems unlikely that investments are lumpy. Moreover, Table 5 shows that 35 percent of firms without loans in 1996 reinvested half or more of their profits, indicating that the lack of external finance does not preclude internally funded investment. (By comparison, 53 percent of firms with loans in 1996 invested half or more of their profits.) Further evidence on this is discussed in Section III, where we use a firm's ability to offer collateral and loans prior to 1996 as measured of 
access to loans in the 1996 reinvestment equation. If investments are lumpy then reinvestment should be positively associated with collateral; we find no significant interaction.

Thus, examining reinvestment of profits independent of access to external finance appears to be reasonable for our data. In the next section, we examine the determinants of the firm's decision to reinvest from its profits (equation (4)). The main hypothesis is that firms reinvest less if they perceive their property rights to be more insecure.

\section{Determinants of Profit Reinvestment}

Security of property rights is positively correlated with profit reinvestment rates at the country level, as we saw in Section I. Reinvestment rates are highest in Poland and Romania, where extralegal payments and payments for protection are lowest and the reliability of the courts is highest. Reinvestment rates are lowest in Ukraine and Russia, where extralegal payments are highest and courts less effective. Reinvestment rates are affected, however, by factors other than property rights.

\section{Basic Specification}

In this section, we estimate the reinvestment-demand equation (4), with the percentage of its profits a firm reinvests as the dependent variable and our property-rights indices as independent variables. Our data on reinvestment rates are categorical rather than continuous, and hence we use ordered probit regressions (although we have checked the robustness of our results using alternative specifications). We control for factors affecting investment demand other than property rights: the industry profit rate (as a 
proxy for expected investment opportunities more generally) ${ }^{18}$, the age of the firm, access to external finance (represented by whether the firm had collateralizable assets), entrepreneur characteristics, and other industry effects.

Table 6 presents the results of these regressions. There are six categories of responses to the reinvestment question, increasing in the rate of reinvestment. A positive coefficient indicates that an increase in the level of the independent variable increases the chance that a firm is in a higher reinvestment category. ${ }^{19}$ We exclude from the regression sample firms that had zero or negative profits in 1996, since we are unable to measure their reinvestment rate. We also exclude firms not operating at the start of the year in 1996. Both startups and spinoffs are included in the initial regressions (first and second columns). Recall that the questions on which the key independent variables are based refer to payments made by firms in the respondent's industry. To be conservative, we therefore report t-values based on standard errors adjusted for clustering for 44 industry/country groups. Adjusting for clustering has only a small effect on the standard errors in these regressions and does not affect the significance level for any of our results.

The first column of Table 6 includes only the index that represents the insecurity of property rights. Greater insecurity is associated with lower levels of profit reinvestment, and this effect is highly significant. The second column adds the variable that indicates the entrepreneur thinks courts are ineffective. Ineffective courts are associated with lower levels of investment as well, an effect significant at the 0.05 level. Additional variables added in the second control for the entrepreneur's estimate of the industry profit rate ${ }^{20}$ and tax rate, the log age of the firm in years, a dummy variable indicating that the firm is a startup and nine industry dummy variables. Older firms invest 
a lower proportion and startups a higher proportion of their profits. Higher tax rates are associated with lower investment rates, though the effect is significant at only the 0.10 level. The regression also controls for the age of the firm and whether the firm is a startup.

Our index for the insecurity of property rights is additive. An alternative index would take a value of one if firms make any one of the three types of payments, and a value of zero otherwise. Both indices have theoretical merit, but the additive index explains the data better. The either/or index is significant $(\beta=-0.27, \mathrm{t}=3.48)$, but has a lower $t$-value and results in a lower $\chi^{2}$ (60.8 vs. 65.4 with the additive index). The additive index can be used to create four dummy variables, the first representing an index value of zero, the second representing an index value of one, and so on. When dummies representing index values of three, two, and one are used in place of the index (with the value zero being the base group), the coefficients are $-0.35,-0.26$ and -0.14 , respectively. These results suggest that the effects of corruption are additive, perhaps because multiple affirmative responses indicate stronger convictions on the part of the entrepreneur. Alternatively, the better performance of the additive index may indicate that those extracting payments do not coordinate their activities, consistent with the model of Shleifer and Vishny (1993).

The first two regressions do not control for country effects. Since much of the variance in security of property rights is across countries rather than within country, this measures the full effect of property rights. However, there may be other factors that vary across countries and affect the demand for investment. If so, then these other countrylevel effects will be correlated with our measures of property rights. The regressions in 
Columns 3-9 control for differences in each industry in each country using 39 industry/country dummy variables. We include interacted controls because the factors affecting investment demand in the food industry in Poland, for example, may differ from factors affecting investment demand in the food industry in Russia. Neither the index of property rights nor the reliability of the courts is much affected by the inclusion of the industry/country dummies, though the index is now significant only at the 0.05 level. ${ }^{21}$

\section{Alternative Specifications}

The regressions in Columns 3-9 also include a set of four variables measuring entrepreneur characteristics. These variables measure the age, years of schooling, and prior work experience of the entrepreneur. The two work experience variables indicate whether the entrepreneur previously was a high level manager in a state-owned enterprise and whether the entrepreneur had prior experience in the private sector. The coefficients of these controls for entrepreneur characteristics (not shown on Table 6) indicate that investment rates are higher for younger entrepreneurs $(\beta=-0.01, \mathrm{t}=2.77$ in the thirdcolumn specification) and for entrepreneurs who were previously high level managers at state-owned enterprises ( $\beta=0.24, \mathrm{t}=2.98$ in the third-column specification). Education and private sector experience have no significant effect.

We split the sample, in the fourth and fifth columns, into firms that are startups and those that were spun off from a state enterprise. For startups, the coefficients are similar to those obtained for the whole sample, though the measure of courts is not significant at the 0.10 level. The industry tax rate is not significant in either subsample. However, the entrepreneur's estimated profit rate for the industry is significant at the 0.10 
level among startups. Among spinoffs, no variable measuring property rights has any effect on investment. The industry profit rate has the wrong sign and is insignificant. There are significant differences between the behavior of spinoffs and startups, with the regressions doing a better job explaining the behavior of startups. Given that most of the spinoffs underwent downsizing after being privatized, other factors may play an important role in determining reinvestment rates for these firms. For the regressions in the sixth, seventh, and ninth columns we limit the sample to startup firms.

The regression in the sixth column uses an alternative index of security of property rights. This alternative index ranges from zero to four - it adds one to the original index if the entrepreneur thinks courts are ineffective for enforcing contracts. As with the original index, a higher value represents less secure property rights. The fourelement index has the expected negative sign, and is significant at the 0.01 level.

Last, we divide the sample by region, first considering investment among startups in Poland, Slovakia and Romania (the seventh column), and then considering all firms in Russia and Ukraine (the eighth column). (The number of startups with non-missing responses in Russia and Ukraine is too small for us to use only startups in this regression.) The two property-rights measures both have the expected sign in the three Eastern European countries. The index is significant at the 0.01 level; the significance of the effectiveness of courts falls below the 0.10 level. In Russia and Ukraine, the effectiveness of courts is significant. The index of property rights is not included in this regression because there is not enough variation in the index in the Russia/Ukraine sample to make the results meaningful. (Only three of 116 firms in the sample answer "no" to any of the three questions in the index!) 
The ordered probit coefficients represent changes in the probabilities of being in each category of investment. Hence, giving an economic interpretation of their magnitude is difficult. To gain a better picture of the effect of property rights on investment, we calculate the probability of being in each investment category conditional on different values of the property rights index. We use the regression reported in the sixth column of Table 6, using the four-element security index. The results are shown in Table 7. The bottom row of the table shows the weighted average reinvestment rate for each value of the index, using the midpoint of each reinvestment category. Firms with the most secure property rights (those with an index value of zero) have an average predicted reinvestment rate of 55.1 percent; those with the least secure property rights have an average predicted reinvestment rate of 33.5 percent. The most insecure firms' investment is therefore 39 percent lower than the investment of the most secure firms.

In sum, the index of property rights has a significant effect on firms' investment rates, especially among de novo startups. We find only weak evidence that tax rates affect investment demand. The lack of robustness in the tax effects may reflect a lack of variance in taxes across firms, since statutory tax rates vary only across countries. Alternatively, perhaps it is the clandestine and unpredictable nature of the unofficial payments, rather than just the fact that some profits will be taken, that discourages firms from investing.

\section{Access to Credit}

Our framework assumes that the decision to invest internally generated funds is independent of access to external funds. It is possible, however, for internal and external 
funds to complement one another. If investment projects are lumpy, then firms may need outside finance in order to undertake investment projects at all. In this case, those not receiving loans would not invest internal funds either. We cannot include a direct measure of whether the firm has a loan because the latent variable - investment demand determines (at least in part) both reinvestment of profits and demand for loans. Instead, we test for the importance of loans by including variables that are correlated with access to finance but that we expect are uncorrelated, or only weakly correlated, with investment demand. ${ }^{22}$ We include two variables, one indicating that the firm has collateralizable assets, and the other indicating the firm received a loan prior to 1996. Both of these variables are strongly correlated with receiving a loan in 1996. Collateral is necessary for access to loans. Only six of 310 firms reporting loans in 1996 said they did not provide collateral. Loans obtained prior to 1996 provide an additional indication of creditworthiness. In most cases (69 percent) where firms had loans prior to 1996 and in 1996 as well, the firm obtained both loans from the same bank. Given that our sample is limited to firms with positive profits in 1996, we believe these two variables are good indications of access to credit. ${ }^{23}$ Neither has a significant effect on the rate of reinvestment. (ninth column of Table 6). The inclusion of the instruments for bank finance has little impact on the magnitude or significance of the coefficient on the index of property rights insecurity. The variable measuring the reliability of courts is now significant at the 0.10 level.

In unreported regressions available from the authors, we pursued an alternative test for an interaction between security of property rights and use of external credit. We included the index of insecurity as an independent variable in a regression with the 
receipt of a loan in 1996 as the dependent variable. We found that the index of insecurity has no effect on the likelihood a firm obtained a loan in 1996. This provides additional evidence that less secure property rights did not encourage entrepreneurs to invest from bank funds rather than from their own profits. In the regressions, both the availability of collateral and receipt of loans prior to 1996 had large and significant effects on the likelihood a firm received credit in 1996, suggesting that banks' willingness to lend is an important determinant of credit availability. The level of unreinvested profits also has a large and significant effect on the likelihood a firm received credit. The last result suggests an indirect link between property rights and credit: firms perceiving property rights as insecure invest less, and so demand less credit. Low levels of observed credit may result from a lack of demand as well as a lack of supply.

\section{Further Robustness Checks}

Table 8 reports regressions that use the components of the index one at a time. We use the sample of startups in these regressions. Among the elements of the index, extralegal payments for government services clearly have the most significant effect (the first column). Payments for protection fall just below the 0.10 level of significance, and payments for licenses is insignificant as well (the third and second columns, respectively).

The fourth, fifth, and sixth columns of Table 8 replace the components of our index with the responses to questions about bribes paid for specific services. All three types of bribes-payments for ongoing registration, payments for fire/sanitary inspection and payments for tax inspection—are negatively and significantly associated with 
reinvestment levels. The sample size in these regressions varies and is smaller than the other regressions because the response rate for these questions is generally lower. The variable representing trust in the courts has the correct sign in all of the regressions reported on Table 8, though it is insignificant in all but one of the specifications (see the last row of coefficients in each column).

Our findings are also robust to alternative ways of defining the dependent variable. Ordinary least squares regressions using the midpoint of the investment categories (i.e., five for the 1-10 percent category, eighteen for the 11-25 percent category, and so on) produces very similar results. Probits for over/under 75 percent reinvestment or over/under 50 percent reinvestment also produce similar findings.

\section{Caveats to Our Interpretation}

In the regressions, we treat property rights as exogenous to the investment decisions of our firms. There are at least two reasons why this may not be a valid assumption. First, higher investment rates may lead to more secure property rights, as in the model of Besley (1995). While it is plausible that very large firms in post-communist transition countries may endogenously create property rights by becoming 'too big to fail,' we do not view this as likely for our firms, given their relatively small size.

Of more concern is the possibility that higher reinvestment rates and more secure property rights may both reflect the optimism of the responding managers. Managers may also attempt to justify an unwillingness to invest by saying that property rights are insecure. In either of these cases, endogeneity of property rights security arises from our inability adequately to control for manager characteristics. We lack direct measures of a 
manager's attitudes, but managers who say property rights are less secure also say their own profits and their industry's profits are higher. Insecurity is also significantly correlated with characteristics of the manager that we can measure. For example, older managers and managers who formerly worked as a high level manager of a state-owned enterprise say property rights are more secure. These correlations suggest there is an important exogenous component of our insecurity index. Nevertheless, the estimated impacts of insecurity on investment may be overstated if unmeasured manager characteristics are important.

Alternatively, our regression coefficients may understate the effects of propertyrights insecurity. Since we surveyed existing firms, our sample omits both failed firms and potential firms that were deterred from entering. Both failure and the decision not to enter presumably reflect the insecurity of property rights. Additionally, because our regressions look at the determinants of firms' marginal investment decisions in their current lines of activity, we cannot pick up possible intersectoral distortions. For example, certain industries might be especially susceptible to extortion; the insecurity of property rights might cause entrepreneurs to shun those industries. If capital is more susceptible to extortion than labor, weak property rights may also cause production to be inefficiently labor-intensive. We have no way of determining the net effect of the biases of opposite directions.

In summary: Weak perceived property rights have a consistently negative effect on reinvestment in our regressions. The index of property rights is significant in all subsamples apart from spin-offs. The measure of trust in courts has a less robust effect on 
reinvestment, but is significant for the full sample. The availability of collateral is not correlated with the reinvestment of profits.

\section{Conclusion}

Firms' investment is affected by the perceived security of property rights, as shown by both our cross-country data and firm-level regressions. Reinvestment rates are lowest in Russia and Ukraine, where bribes for government services and licenses are common, firms make payments for protection, and the courts are least effective, and highest in Poland and Romania, where property rights are the most secure. Within countries, also, there is also significant variation, as our firm-level regressions indicate. The entrepreneurs who perceive their property rights to be the least secure reinvest 32 percent of their profits, while those with the most secure property reinvest 56 percent. Insecurity of property rights, all else equal, reduces a firm's investment by over a third.

Most of the firms say they were able to offer collateral to banks (more than threequarters of the firms in each of the countries). Lack of collateral, therefore, does not appear to have been a binding constraint on firms' investment. There are two reasons why, until now, external credit has not been essential for private-sector development. First, insecure property rights mean firms have limited incentive to invest and therefore little demand for external finance (especially in Russia and Ukraine). Second, the high profits of early entrants in all these transition economies meant that firms that wished to invest were able to do so. The potential for using retained earnings as a source of investment is seen from the fact that in, all five countries, unreinvested profits exceed the 
funds provided by banks. Our evidence indicates, then, that secure property rights have been both necessary and sufficient for investment.

Although the firms have had little demand for external finance at the time of our survey, they will begin to need access to credit as these economies develop their marketsupporting institutions. This is because legal and bureaucratic reforms increase the demand for investable funds by solidifying property rights ${ }^{24}$ and because profits will be driven down to normal levels as transaction costs fall and market competition increases, so investment from internal funds will not be sustainable. 


\section{References}

Acemoglu, Daron; Johnson, Simon and Robinson, James. "The Colonial Origins of Comparative Development: An Empirical Investigation,” American Economic Review 91 (5), December 2001, pp. 1369-1401.

Berkowitz, Daniel and DeJong, David N. "Accounting for Growth in Post-Soviet Russia," unpublished, University of Pittsburgh, June 2000.

Besley, Timothy. "Property Rights and Investment Incentives: Theory and Evidence from Ghana,” Journal of Political Economy 103 (5), October 1995, pp. 903-937.

Bratkowski, Andrzej; Grosfeld, Irena and Rostowski, Jacek. "Investment and Finance in De Novo Private Firms: Empirical Results from the Czech Republic, Hungary, and Poland," Economics of Transition 8 (1), 2000, pp. 101-116.

Demirgüç-Kunt, Asli and Maksimovic, Vojislav. "Law, Finance, and Firm Growth," Journal of Finance 53 (6), December 1998, pp. 2107-2137.

\section{Djankov, Simeon; La Porta, Rafael; Lopez-de-Silanes, Florencio and Shleifer,} Andrei. "The Regulation of Entry," unpublished, Harvard and The World Bank, July 2000.

European Bank for Reconstruction and Development 1996. Transition Report, 
London.

Federal Reserve Board of Governors. National Survey of Small Business Finance, Washington, DC, 1994.

Frye, Timothy and Shleifer, Andrei. "The Invisible Hand and the Grabbing Hand," American Economic Review, Papers and Proceedings 87 (2), May 1997, pp. 354358.

Hellman, Joel; Jones, Geraint; Kaufmann, Daniel and Schankerman, Mark. "Measuring Governance and State Capture: The Role of Bureaucrats and Firms in Shaping the Business Environment," Workshop on The Institutional Foundation of a Market Economy, Berlin, February 2000.

Johnson, Simon; Kaufmann, Daniel and Shleifer, Andrei. "The Unofficial Economy in Transition.” Brookings Papers on Economic Activity, 2 Fall 1997, pp. 159-221.

Johnson, Simon and Loveman, Gary W. Starting Over in Eastern Europe, Boston, Harvard Business School Press, 1995.

Johnson, Simon; McMillan, John and Woodruff, Christopher. "Courts and Relational Contracts," Journal of Law, Economics, and Organization 18 (1), Spring 2002, pp. 221-277. 
Knack, Stephen and Keefer, Philip. "Institutions and Economic Performance: CrossCountry Tests Using Alternative Institutional Measures,” Economics and Politics 7 (3), November 1995, pp. 207-228.

La Porta, Rafael; Lopez-de-Silanes, Florencio; Shleifer, Andrei and Vishny, Robert. "Legal Determinants of External Finance," Journal of Finance 52 (3), July 1997, pp. 1131-1150.

La Porta, Rafael, Florencio Lopez-de-Silanes, Andrei Shleifer and Robert W. Vishny. "Law and Finance," Journal of Political Economy, 106 (6), December 1998, pp. 1113-55.

\section{La Porta, Rafael, Florencio Lopez-de-Silanes, Andrei Shleifer and Robert W.} Vishny. "Investor Protection and Corporate Governance." Journal of Financial Economics 58 (1-2), October-November 2000, pp. 3-28.

Levine, Ross. "Financial Development and Economic Growth: Views and Agenda," Journal of Economic Literature 35 (2), June 1997, pp. 688-726.

Lotspeich, Richard. "An Economic Analysis of Extortion in Russia," unpublished, Indiana State University, 1996. 
Mauro, Paolo. “Corruption and Growth," Quarterly Journal of Economics 110 (3), August 1995, pp. 681-712.

McMillan, John. "Markets in Transition," in Advances in Economics and Econometrics: Theory and Applications, ed. David M. Kreps and Kenneth Wallis, Cambridge: Cambridge University Press, 1997.

Meyendorff, Anna. "Tax Avoidance and the Allocation of Credit," unpublished, William Davidson Institute, University of Michigan, May 1998.

Myers, Stewart C., and Majluf, Nicholas S. "Corporate Financing and Investment Decisions When Firms Have Information that Investors Do Not Have," Journal of Financial Economics 13 (2), June 1984, pp. 187-221.

Naughton, Barry. Growing Out of the Plan, New York, Cambridge University Press, 1995.

Rajan, Raghuram, and Zingales, Luigi. "Financial Dependence and Growth," American Economic Review 88 (3), June 1998, pp. 559-586.

Shleifer, Andrei. "Government in Transition," European Economic Review 41 (3-5), April 1997, pp. 385-410. 
Shleifer, Andrei, and Vishny, Robert W. "Corruption," Quarterly Journal of Economics 108 (3), August 1993, pp. 599-617.

Shleifer, Andrei, and Vishny, Robert W. The Grabbing Hand: Government Pathologies and their Cures, Cambridge, Harvard University Press 1998.

Shyam-Sunder, Lakshmi, and Myers, Stewart C. "Testing Static Tradeoff Against Pecking Order Models of Capital Structure," Journal of Financial Economics 52 (1), February 1999, pp. 219-244.

Svensson, Jakob. "Investment, Property Rights and Political Instability: Theory and Evidence," European Economic Review 42 (7), July 1998, pp. 1317-1341. 


\footnotetext{
*Johnson: Sloan School of Management, MIT, sjohnson@mit.edu. McMillan: Graduate School of Business, Stanford University, mcmillan_john@gsb.stanford.edu. Woodruff: Graduate School of International Relations and Pacific Studies, UCSD, cwoodruff@ucsd.edu. We thank Timothy Besley, Bengt Holmström, Takeo Hoshi, James Rauch, Andrei Shleifer and two anonymous referees for comments, Todd Mitton for help with the Worldscope data, Mark Schankerman for help in facilitating the surveys, and the European Bank for Reconstruction and Development for funding the surveys in Poland, Slovakia, and Romania and the National Council for Soviet and East European Research for funding the surveys in Russia and Ukraine. For support, Johnson thanks the MIT Entrepreneurship Center and McMillan thanks the Stanford Graduate School of Business.
}

${ }^{1}$ For more detail on the survey see Appendices A, B and C, which are on the American Economic Review web site, www.XXX.) The questionnaire and the complete raw data are available at http://www-irps.ucsd.edu/faculty/cwoodruff/data.htm

${ }^{2}$ High profits to new entrants appear to have been common in the early stages of reform in the formerly planned economies. China's newly entering rural firms had an average rate of profit on capital of 40 percent in 1978, the first year of reform; in subsequent years this profit rate fell as China's marketization proceeded (Barry Naughton, 1995, p.150). Anecdotal evidence that early entrants in Poland earned high profits is given in Johnson and Gary W. Loveman (1995).

${ }^{3} \mathrm{We}$ chose these three countries on the basis of country-level measures that indicated substantial variation in institutional environment. The survey is described in more detail in Appendix A, and Appendix C summarizes our key questions about finance, profits, investment, and property rights. (These appendices are available at www.XXX.) 
${ }^{4}$ For questions where the range of potential responses ranged too widely to use categories, we did ask for specific nominal amounts. In these cases -for example, when we asked firms how much capital they invested in the firm at startup - response rates were much lower.

${ }^{5}$ This way of asking about sensitive issues, such as property rights and underground economic activity, was developed by Daniel Kaufmann in his earlier empirical work. See, for example, Joel Hellman, Geraint Jones, Kaufmann, and Mark Schankerman (2000). The results seem consistent with available cross-country evidence and across surveys.

${ }^{6}$ We asked entrepreneurs to report taxes as a percent of total sales. Firms in Eastern Europe and the former Soviet Union routinely underreport sales to avoid taxes and extortion (Johnson, Kaufmann, and Shleifer, 1997). In separate questions, entrepreneurs indicated that the percentage of sales hidden by firms in their industry is about 41 percent in Ukraine, 29 percent in Russia, and around 6 percent in the other three countries. It may be that some entrepreneurs reported taxes and profits as a percent of official sales rather than total sales. If so, then the tax burden and profit rates will be overstated, especially for Russia and Ukraine. But this should not affect our analysis of reinvestment rates.

${ }^{7}$ Responses to questions about the entrepreneur's own profits were provided in categories. Appendix B (at www.XXX) explains how the numbers in Table 3 were calculated from these responses. The profit data are also compared in Appendix B to data from the National Survey of Small Business Finance, conducted in 1993 in the United States among similarly sized firms (Federal Reserve Board of Governors, 1994).

${ }^{8}$ Throughout, we use the reported rate of profit as a proxy for the firm's cash flow available for reinvestment. In reality, profits and cash flow may diverge for a number of reasons, in particular depreciation. However, information on depreciation recorded by the firms is not available from the survey. 
${ }^{9}$ Worldscope also has data for Russia and Slovakia, although this is available for fewer firms. The average profit-sales ratio in Russia for 1999 is 7.11 percent, although firms with substantial market power show higher profit rates. Almost all the Slovak firms show losses.

${ }^{10}$ T-tests comparing the profit rate in the early period (1990-92) with the profit rate in the last period (1994-96) indicate that the drop in first-year profit rates is significant at the 1 percent level in Poland $(t=3.38)$ and in Slovakia $(t=2.96)$, but not in Romania $(t=0.99)$, Russia $(t=$ $0.30)$, or Ukraine $(\mathrm{t}=0.61)$.

${ }^{11}$ See Appendix B (at www.XXX) for the details of these calculations as well as some caveats to their interpretation.

12 There are no reliable comparable data on credit to the private sector across transition countries, but the ratio of broad money to GDP provides a rough indicator. In 1996, broad money was 37.5 percent of GDP in Poland, 28.9 percent in Romania, 13.1 percent in Russia, 71 percent in Slovakia, and 11.16 percent in Ukraine (EBRD 1997). The real money supply in Russia and Ukraine fell dramatically between 1991 and 1996, which partially accounts for credit becoming harder to get in these two countries (EBRD 1997). Of course, our sample has quite different characteristics from the large state or privatized firms that receive (or do not receive) most of the credit in these transition economies.

${ }^{13}$ When lines of credit are excluded, loans were 5.8 percent of sales among the small manufacturers in the NSSBF survey. Both of these averages assign a value of zero to firms without loans. (See Appendix B, at www.XXX, for more discussion of the NSSBF data.)

${ }^{14}$ While the response rate to the collateral question was more than 99 percent in Romania, it was only 76 percent in Ukraine and 61 percent in Russia. If nonrespondents are less likely to have collateral, then the numbers in Table 2 may overstate the availability of collateral in Russia and Ukraine. Still, as a lower bound (taking all nonrespondents as having no collateral), 
the survey indicates that more than half of firms in Russia (53 percent) and Ukraine (57 percent) are able to offer collateral.

${ }^{15}$ Apparently respondents misunderstood what we were asking. This question may not have been translated properly.

${ }^{16}$ The correlations between property rights and access to credit are driven primarily by differences across countries. When Poland, Slovakia and Romania are separated from Russia and Ukraine, insecure property rights are positively correlated with a lack of collateral. However, the correlations are low, all below 0.11 , and there is no correlation between security of property rights and having had a loan before 1996. In Russian and Ukraine, firms with less secure property rights are more likely to have collateral to offer and to have had a loan before 1996.

17 Because of the categorical responses, we cannot determine how many firms obtained new loans and invested more than 100 percent of their profits, though it is likely that some did. Just over a fifth of the firms reported investing more than 75 percent of profits, the highest reinvestment category. In Poland 35 percent of firms reported investing at least 75 percent of profits.

${ }^{18}$ We do not use the firm's own profit rate due to concern about reverse causation: higher investment levels might lead to higher rates of profits. Given our belief that the manager's estimate of industry conditions is based on his own experience, use of industry profits does not completely eliminate endogeneity concerns. However, none of the results we report are altered if we use the firm's profit rate during its first year of operation, or exclude all measures of profits.

${ }^{19}$ We have run all of the regressions using ordinary least squares, using the midpoint of the reinvestment categories, with robust standard errors. The results are qualitatively similar to those reported. We prefer the ordered probit because it does not require the assumption that investment rates are exactly at the midpoint of the categories specified in the survey. (See 
Appendix B, at www.XXX, for the details on the six categories of responses to the reinvestment question.)

${ }^{20}$ We use the entrepreneur's estimate of industry profits rather than the firm's own profits because we believe the former are more likely to represent the expected profits from new investments. Additionally, own profits may be determined in part by reinvestment, creating endogeneity problems. Nevertheless, when we rerun all of the regressions in Table 6 with own profits replacing industry profits, we find that own profits are significant everywhere that industry profits are significant. The property rights index and courts results are not affected.

${ }^{21}$ Because response rates were lower in Russia and Ukraine, only 14 percent of the observations in the regressions are firms in those countries. This may explain why the country controls have only a small impact on the property rights variables.

${ }^{22}$ Because investment opportunities may be correlated across time within a firm, we had some concern that either of these variables might be partially endogenous to current reinvestment rates. Their insignificance in the reinvestment equation suggests that endogeneity of our measures through temporal correlation of investment rates is not a serious problem.

${ }^{23}$ Our results are consistent with those found by Andrzej Bratkowski, Irena Grosfeld and Jacek Rostowski (2000), who find for a sample of new firms in the Czech Republic, Hungary and Poland that loans are significantly associated with collateral and past loans.

${ }^{24}$ Low reinvestment may be the result of a high required rate of return, rather than a high probability of expropriation, because imperfect financial markets mean entrepreneurs bear a large amount of idiosyncratic risk. Improved capital markets would then facilitate investment because they would increase diversification possibilities and reduce idiosyncratic risk. 


\section{Appendix A: The Sample and the Survey}

The data reported here are from surveys undertaken in Russia and Ukraine in May and June 1997, and in Poland, Romania and Slovakia in September-December 1997. Pilot surveys were undertaken in Russia and Ukraine in January-February 1997, in Poland and Slovakia in March 1997 and in Romania in August 1997. The sample of about 300 firms in each country was drawn from a list provided by the country's official statistical office. In order to increase the cross-country comparability of the sample, the initial selection was limited to one medium-sized city in each country: Katowice (Poland), Brasov (Romania), Bratislava (Slovakia), Volgograd (Russia) and Dnepopetrovsk (Ukraine). Only in Slovakia did we have trouble identifying a large enough sample of firms meeting our size criteria who were willing to participate. In the final sample, about one-quarter of the Slovakian firms are located in Bratislava, onequarter in Kosice, and the remaining half are spread across seven other cities.

Participation rates were high among the firms contacted-in excess of $70 \%$ in Poland and Romania, and $68 \%$ in Slovakia. We believe the resulting sample is reasonably representative of small and medium-sized manufacturing firms in each country, though it is not a census. ${ }^{1}$

Appendix Table 1 provides a summary of the characteristics of firms in the sample. Most were started in 1990 or after; many within 3 years of the survey. Only in Poland was a significant share of the firms founded before 1988. The majority of firms in Russia and Ukraine were privatized, or spun off from state-owned enterprises; the majority in the other three countries started from scratch, with none of their equipment coming from state-owned enterprises.

\footnotetext{
${ }^{1}$ In Russia, in particular, there is considerable regional variation in new firm activity, so results for one city are not necessarily true of other regions. See Berkowitz and DeJong (2000).
} 
At least $85 \%$ of the entrepreneurs in each of the countries report that they have previous experience working in a state enterprise. Previous work experience in the private sector is much more common for startup firms than spin-offs. At least $29 \%$ of startup entrepreneurs have prior private sector experience in every country except Romania. In all five countries the educational background of entrepreneurs is similar; the average amount of schooling is 15-16 years everywhere.

Measured by employment, in all five countries spinoffs were much larger in their first year of operation than the startups. The startups were smallest at birth in Slovakia and largest in Poland, though there is not a large difference among the countries in the average size of startups in their first year.

In Poland, Romania and Slovakia, the sample was drawn so that one-quarter of the firms were from the same industry, metal parts and products. Nearly a fifth of the Ukrainian firms and one-eighth of the Russian firms also produce metal products. The remaining firms are spread across manufacturing sectors, as shown in Appendix Table 1.

The survey was administered face-to-face in the local language by interviewers contracted in each country, with responses provided by the entrepreneur (typically also the general manager) or deputy general manager of each firm. The largest part of the survey is a series of questions related to the longest running and newest customer and supplier relationships. There are also sections on the resolution of contract disputes with customers and suppliers, access to formal bank finance, hidden and unofficial payments, and a set of general questions regarding the size and profitability of the firms. 


\section{Appendix B: Finance variables}

Because of the sensitivity of the issues, entrepreneurs were asked for profit and reinvestment rates by category. For profits as a percent of sales, the categories were: negative, $0 \%, 1-10 \%, 11-20 \%, 21-40 \%$ and more than $40 \%$. For the percentage of profits reinvested, the categories were $0 \%, 1-10 \%, 11-25 \%, 26-49 \%, 51-75 \%$ and more than $75 \%$. The midpoint of each category was used in compiling Table 1. For example, firms reporting profits between 1 and $10 \%$ of sales were assigned profit rates of $5 \%$ of sales, those reporting profits $11-20 \%$ of sales, $15 \%$, and so on. Firms reporting negative profits were assigned a value of $-5 \%$ of sales and firms reporting profits of more than $40 \%$ of sales were assigned values of $45 \%$ of sales. Only a small percentage of the firms have profits which are negative $(5.2 \%)$ or greater than $40 \%$ of sales $(2.3 \%)$.

To benchmark our survey responses, we compare them with data from the National Survey of Small Business Finances (NSSBF), conducted in the United States in 1993 (Federal Reserve Board of Governors, 1994). Of 4637 firms in the NSSFB, 344 are manufacturers with between 10 and 270 employees. The average size of firms in this subsample of the NSSBF is 77 employees, somewhat larger than the average of 55 employees in our sample. The US firms are more likely to report negative profits $(23 \%$ vs. $5 \%$ of the firms in our survey) or positive profits below $10 \%$ of sales (60\% vs. $35 \%$ ), and less likely to report profits of $10-20 \%$ of sales ( $8 \%$ vs. $40 \%$ ) or profits of $20-40 \%$ of sales ( $2 \%$ vs. $15 \%)$. In both samples, $2 \%$ reports profits in excess of $40 \%$ of sales. The average profit rate for US manufactures is $3.4 \%$ of sales, lower than each of the countries in our survey. This average is impacted by values in the tails of the distribution. When the US data are recoded to correspond to the categories in our survey, (i.e., profits above 0 and less than $10 \%$ recoded as $5 \%$, and so on), the average profit in the sample of US manufacturers is $4.4 \% .^{2}$

\footnotetext{
${ }^{2}$ When manufacturers with less than 10 or more than 270 employees are included, the US profit rates are higher $-4.8 \%$ using the raw data and $6.5 \%$ using the categories.
} 
The higher profit rate found when the US data is recoded to our categories raises the question of whether our estimated profits are similarly biased upward. Two factors account for approximately equal shares of the upward bias in the US estimates. First, the categorical data crops the lower (and upper) tail of the distribution. The average profit rate in the lower tail is much lower than $-5 \%$ in the US data. Since the lower tail is much smaller in our data, we expect that $-5 \%$ is a better representation for our data. Second, within each category, the distribution is weighted toward firms with lower profit levels. Thus there are more firms in the US sample earning profits that are $1 \%-5 \%$ of sales than firms earning profits that are $6 \%-10 \%$ of sales. As a result, using the midpoint of the range overstates the average profit rate in the range. For our data, the number of firms reporting $11-20 \%$ profits is as large as the number reporting 1-10\%. So we would not expect the midpoint to be biased for the 1-10\% group. On the other hand, there are a lower number of firms in higher profit categories in our data, as in the US. In the US data, the average profit rate of all firms earning $10-20 \%$ is $14 \%$, and the average for firms earning $20-40 \%$ is $28 \%$. Using these values with our data lowers the average profit rate shown in the first line of Table 1 to $9.4 \%$ in Poland, 5.4\% in Slovakia, $12.2 \%$ in Romania, $19.4 \%$ in Russia and $17.0 \%$ in Ukraine. Note that the categories do not affect the reinvestment regressions shown in Table 6 because responses to the industry profit rate are continuous rather than categorical.

For reinvested profits as a percent of sales, there is another potential bias in our estimates. We obtain the estimate of each firm's internally generated investment as a percent of sales by multiplying estimated profits as a percent of sales by the reinvestment rate. Across categories there is a positive correlation between reinvestment rates and profit rates. If the same is true within categories, then the numbers of Table 1 may understate the reinvestment of profits and overstate the unreinvested profits.

To give some idea of the potential magnitude of the error caused by using the midpoints of ranges, we calculated a lower bound on the unreinvested profits in the five 
countries. We did this by taking the lowest value in each range for profits (e.g., $1 \%$ for the $1 \%-10 \%$ category) and the highest value in each range for the reinvestment rate (e.g., $10 \%$ for $1 \%-10 \%$ ). These provide a lower bound on the profit rate, and an upper bound on the reinvestment rate. Multiplying the lower-bound profit rate by $100 \%$ minus the upper-bound reinvestment rate provides a lower bound for profits that are not reinvested. The lower bound estimates of unreinvested profits as a percent of sales are $7.5 \%$ in Ukraine (compared to $12.3 \%$ on Table 1), $6.7 \%$ in Russia (11.7\%), $2.7 \%$ in Romania (5.7\%), 2.3\% in Poland (4.8\%) and 1.5\% in Slovakia (3.6\%). The levels in Russia and Ukraine, which certainly underestimate the level of unreinvested profits, are still far above the average level of bank credit in any of the five countries (see Table 2).

Finally, the data on Tables 1 and 2 are unweighted averages of the firms in the sample. Since our loan regressions (not reported but available from the authors) indicate that larger firms are more likely to receive loans, the data may understate the importance of bank credit in these countries. We have also calculated weighted averages for loans, reinvested profits and unreinvested profits, using the number of employees as weights. Employment-weighted data for bank credit and unreinvested profits produce the same pattern as the unweighted data in four of the five countries. In Slovakia, however, employment-weighted bank loans average $3.9 \%$ of sales (compared with an unweighted average of $2.5 \%$ shown on Table 2) and employment-weighted unreinvested profits average $3.3 \%$ of sales. Hence, in Slovakia, the employment-weighted data suggest that bank credit is larger than the level of unreinvested profits. 


\section{Appendix C}

Relevant Excerpts from the Questionnaire

The purpose of this survey is to gather information on institutional constraints and adaptation in SME Development in Poland/Slovakia/Romania (Interviewer: Read out appropriate country). This study is commissioned by the European Bank for Reconstruction and Development (EBRD) and MEMRB were charged with the responsibility of administering this questionnaire. Results from this survey will assist the Bank to formulate its development strategies towards the SME sector. The information obtained here will be treated as strictly confidential. No accurate financial details are needed, only approximations on the spot and to the best of your memory.

(29) From which source did you get your start-up capital in the beginning and what was the percentage share from each source?

\begin{tabular}{|c|c|c|c|}
\hline & YES & NO & $\begin{array}{c}\text { Percent } \\
\text { Share } \\
(\%)\end{array}$ \\
\hline 1 Your own savings & 1 & 2 & \\
\hline 2 Savings of family & 1 & 2 & \\
\hline 3 Financing from other private firms or individuals & 1 & 2 & \\
\hline 4 Financing from a state enterprise & 1 & 2 & \\
\hline 5 A loan & 1 & 2 & \\
\hline 6 Issuing shares to the public & 1 & 2 & \\
\hline 7 Other: (specify) & 1 & 2 & \\
\hline
\end{tabular}

\begin{tabular}{|c|c|c|}
\hline & YES & $\mathrm{NO}$ \\
\hline 1 A State bank & 1 & 2 \\
\hline 2 A Private bank & 1 & 2 \\
\hline 3 A friend & 1 & 2 \\
\hline 4 A family member & 1 & 2 \\
\hline 5 A domestic private firm & 1 & 2 \\
\hline 6 A domestic state firm & 1 & 2 \\
\hline 7 A foreign firm & 1 & 2 \\
\hline 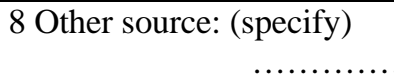 & 1 & 2 \\
\hline
\end{tabular}


(183) Even if you never had a contract dispute could you please tell me which of the following third parties can enforce an agreement with a customer or supplier?

\begin{tabular}{|l|c|c|}
\cline { 2 - 3 } \multicolumn{1}{c|}{} & YES & NO \\
\hline 1 Court & 1 & 2 \\
\hline 2 The national government & 1 & 2 \\
\hline 3 The local government & 1 & 2 \\
\hline 4 A non-governmental organisation (such as a trade association & 1 & 2 \\
\hline 5 Other & 1 & 2 \\
\hline 6 There is no one & 1 & 2 \\
\hline
\end{tabular}

(184) Even if you never had a contract dispute could you please tell me if there is anyone who assists in arbitrating a dispute or negotiating a settlement with a customer or supplier?

\begin{tabular}{|l|c|c|}
\cline { 2 - 3 } \multicolumn{1}{c|}{} & YES & NO \\
\hline 1 Local Government Agency & 1 & 2 \\
\hline 2 National Government Agency & 1 & 2 \\
\hline 3 Trade association & 1 & 2 \\
\hline 4 Middleman or wholesaler & 1 & 2 \\
\hline 5 Other & 1 & 2 \\
\hline 6 There is no one & 1 & 2 \\
\hline
\end{tabular}

(210) What percentage of your time as a top entrepreneur is devoted to the following activities:

1 Internal matters:

809-10\}

2 External matters with firms:

$\% \quad\{811-12\}$

$3 \quad$ Matters related to all levels of government/regulatory: ................. $\%$ \{813-14\}

(Including taxes, licences, labour and trade regulations) $100 \%$

(211) Of the time dealing with other firms, what percent of your time is spent

Dealing with existing customers and suppliers $\%$

Searching for new suppliers and customers

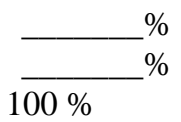

\section{CREDIT}

(212) What are your accounts payable as a percentage of monthly sales? .............\%

(213) What are your accounts receivable as a percentage of monthly sales?............\%

(214) Have you ever had a loan/credit from a bank or a formal financial institution?

$$
\begin{array}{llll}
\text { Yes } & 1 & & \text { Q 216 } \\
\text { No } & 2 & & \text { Q 215 }
\end{array}
$$


(215) Even if you haven't had a successful loan application, did you offer the following kinds of collateral

\begin{tabular}{|l|c|c|}
\cline { 2 - 3 } \multicolumn{1}{c|}{} & YES & NO \\
\hline Equipment & 1 & 2 \\
\hline Land & 1 & 2 \\
\hline Commercial real estate (e.g office or factory space) & 1 & 2 \\
\hline Residential real estate (e.g apartment or house & 1 & 2 \\
\hline Other (specify) & 1 & 2 \\
\hline
\end{tabular}

\section{[GO TO Q VIII FINAL SECTION]}

\section{$\underline{\text { Loan/Credit in } 1996}$}

(216) In 1996, did you receive credit from a bank or a formal financial institution?

$$
\begin{array}{lll}
\text { Yes } & 1 & \text { Q 217 } \\
\text { No } & 2 & \text { Q 226 }
\end{array}
$$

(217) How many different banks or formal financial institutions did you receive credit from?

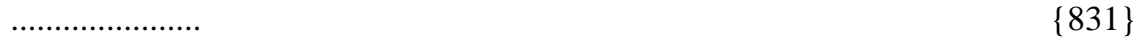

If you borrowed from more than one source, please answer the following questions referring to the bank or formal financial institution that has given you the largest loan.

(218) How large was this credit as a percent of monthly sales? $\%$

(223) How much collateral did you provide as a percent of the loan

\begin{tabular}{|c|c|c|}
\hline & YES & $\mathrm{NO}$ \\
\hline 1 Equipment & 1 & 2 \\
\hline 2 Land & 1 & 2 \\
\hline 3 Commercial real estate (e.g office or factory space) & 1 & 2 \\
\hline 4 Residential real estate (e.g apartment or house & 1 & 2 \\
\hline 5 Other (specify) & 1 & 2 \\
\hline
\end{tabular}
$\% \quad\{838-9\}$

(224) What kind of collateral did you provide

(225) If you received credit from this bank or financial institution before 1996 in what year did you first get credit from this bank?

(249) In 1996, what were profits after tax as a percentage of sales?

$\begin{array}{ll}1 & \text { Negative } \\ 2 & 0 \% \\ 3 & 1-10 \% \\ 4 & 11-20 \% \\ 5 & 21-40 \% \\ 6 & \text { More than } 40 \%\end{array}$


(250) How much did you re-invest out of profits during 1996 ?

$\begin{array}{ll}1 & 0 \% \\ 2 & 1-10 \% \\ 3 & 11-25 \% \\ 4 & 26-49 \% \\ 5 & 50-75 \% \\ 6 & \text { More than } 75 \%\end{array}$

(254) It is thought that many firms in your industry, in order to survive and grow, may need to misreport their operational and financial results. Please estimate the degree of misreporting by firms in your area of activity.

$$
\begin{array}{lc}
\text { hidden sales as percent of actual sales } & \{1007-09\} \\
\text { hidden salaries as percent of actual salary bill } & \{1010-12\} \\
\text { inputs and materials costs as percent of actual costs } & \{1013-15\} \\
\text { (note: this should be more than 100\% if there is misreporting) } \\
\text { reported exports as percent of actual exports } & \{1016-18\} \\
\quad \text { (may be greater than or less than 100\%) } & \\
\text { reported imports as percent of actual imports } & \text { (may be greater than or less than 100\%) }
\end{array}
$$

(255) How much do firms pay for expert assistance (e.g., accountants, lawyers, auditors, other) in dealing with government regulations per year?

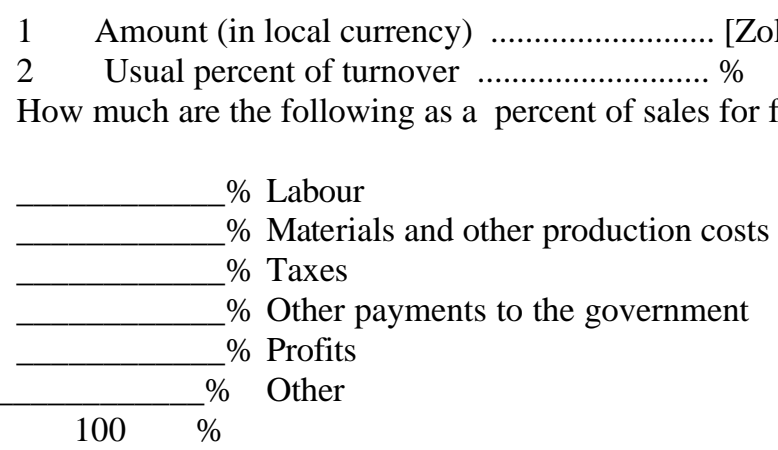

(256) How much are the following as a percent of sales for firms in your sector

$\{1041-42\}$

(257) It is thought that some firms may need to make a payment for "protection" of their activities. Do you think this is generally true for firms in your sector?

$$
\begin{array}{ll}
\text { Yes } & 1 \\
\text { No } & 2
\end{array}
$$

(258) How much would a typical firm in your sector be likely to pay per month?

1 Amount (in local currency) [Zolty/Koruna/Leu]

2 Usual percent of turnover $\%$

(259) It is thought that some firms may need to make indirect or direct payments to government officials to obtain permissions, licences and regulations. Do you think this is generally true for firms in your sector?

$$
\begin{array}{ll}
\text { Yes } & 1 \\
\text { No } & 2
\end{array}
$$


(260) How much would a typical firm in your sector be likely to pay per month?
$1 \quad$ Amount (in local currency)
[Zolty/Koruna/Leu]
$\{1054-60\}$
2 Usual percent of turnover $\%$

(261) It thought that some firms in addition to official payments for government services, may also need to make unofficial or extralegal payments. Do you think this is generally true for firms in your sector?
Yes
1
No
2

(262) Please estimate the size of official and unofficial payments for firms in your sector.

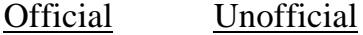

1 Phone line installation

2 Initial enterprise registration

3 Continuing registration requirements (per annum)

4 Single visit of fire/sanitary inspector

5 Quarterly interaction with tax inspector

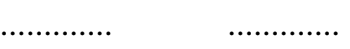

$\{1107-16\}$

Production or office space at a state enterprise (per month)

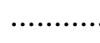

..............

(n............

$\{1117-26\}$

7 Electricity (per month)

8 Gas (per month)

9 Obtaining necessary permissions to export

….................

$\{1127-36\}$

10 Border crossing with customs (percent of goods value)

….........

.............

$\{1137-46\}$

11 Obtaining permissions to import

..............

(n...........

$\{1147-56\}$

12 Access to credit at lower than market interest rates

$\{1157-66\}$

$\{1167-76\}$

$\{1207-16\}$

.............

(n.............

$\{1217-26\}$

$\{1227-36\}$

...........

$\{1237-46\}$ 
Table 1

Perceived Security of Property Rights

Percent of respondents who say firms make extralegal payments for government services

Percent of respondents who say firms make extralegal payments for licenses

Percent of respondents who say firms make payments for protection

Percent of respondents who say firms make unofficial payments for ongoing registration

Percent of respondents who say firms make unofficial payments for fire/sanitary inspection

Percent of respondents who say firms make unofficial payments for tax inspection

Tax payments to government as a percent of sales for firms in industry

Percent of respondents who say courts cannot be used to enforce contracts

Number of Entrepreneurs Surveyed

\begin{tabular}{rrrrrr} 
All countries & Poland & Slovakia & Romania & Russia & Ukraine \\
\hline & & & & & \\
$37.3 \%$ & $20.1 \%$ & $38.2 \%$ & $20.0 \%$ & $91.2 \%$ & $86.9 \%$ \\
1117 & 298 & 306 & 315 & 114 & 84 \\
$37.9 \%$ & $19.3 \%$ & $42.2 \%$ & $17.0 \%$ & $91.7 \%$ & $87.5 \%$ \\
1128 & 300 & 303 & 317 & 120 & 88 \\
& & & & & \\
$24.4 \%$ & $7.9 \%$ & $14.9 \%$ & $0.6 \%$ & $92.9 \%$ & $88.8 \%$ \\
1163 & 302 & 308 & 320 & 126 & 107 \\
& & & & & \\
$14.0 \%$ & $0.4 \%$ & $3.0 \%$ & $19.1 \%$ & $80.0 \%$ & $76.9 \%$ \\
805 & 234 & 236 & 267 & 55 & 13 \\
$19.2 \%$ & $2.8 \%$ & $12.1 \%$ & $21.8 \%$ & $67.9 \%$ & $91.2 \%$ \\
881 & 254 & 248 & 289 & 56 & 34 \\
$12.9 \%$ & $0.8 \%$ & $2.5 \%$ & $17.3 \%$ & $75.6 \%$ & $85.0 \%$ \\
& & & & & \\
$18.9 \%$ & $15.5 \%$ & $16.4 \%$ & $17.2 \%$ & $26.9 \%$ & $28.0 \%$ \\
1130 & 277 & 278 & 321 & 119 & 135 \\
$31.6 \%$ & $27.1 \%$ & $32.1 \%$ & $13.1 \%$ & $44.2 \%$ & $45.4 \%$ \\
1470 & 303 & 308 & 321 & 269 & 269 \\
1471 & 303 & 308 & 321 & 269 & 270
\end{tabular}

Note: The number of observations is given below each response level. 
Table 2

Correlations Among Various Indicators for the Security of Property Rights

\begin{tabular}{|c|c|c|c|c|c|c|c|c|c|c|}
\hline & $\begin{array}{l}\text { Payments } \\
\text { for services }\end{array}$ & $\begin{array}{l}\text { Payments } \\
\text { for licenses }\end{array}$ & $\begin{array}{l}\text { Payments } \\
\text { for protection }\end{array}$ & $\begin{array}{c}\text { Index of } \\
\text { property rights }\end{array}$ & $\begin{array}{l}\text { Courts } \\
\text { enforce }\end{array}$ & $\begin{array}{l}\text { Taxes as a } \\
\% \text { of sales }\end{array}$ & $\begin{array}{l}\text { Bribes } \\
\text { registration }\end{array}$ & $\begin{array}{l}\text { Bribes } \\
\text { fire/sanitary }\end{array}$ & $\begin{array}{c}\text { Bribes } \\
\text { taxes }\end{array}$ & $\begin{array}{c}\text { Loan before } \\
1996\end{array}$ \\
\hline $\begin{array}{l}\text { Firms make extralegal } \\
\text { payments for licenses }\end{array}$ & $\begin{array}{c}0.66 \\
(1105,<.01)\end{array}$ & & & & & & & & & \\
\hline $\begin{array}{l}\text { Firms make payments for } \\
\text { protection }\end{array}$ & $\begin{array}{c}0.52 \\
(1109,<.01)\end{array}$ & $\begin{array}{c}0.54 \\
(1122,<.01)\end{array}$ & & & & & & & & \\
\hline $\begin{array}{l}\text { Index for insecurity of } \\
\text { property rights }\end{array}$ & $\begin{array}{c}0.87 \\
(1099,<.01)\end{array}$ & $\begin{array}{c}0.87 \\
(1099,<.01)\end{array}$ & $\begin{array}{c}0.79 \\
(1099,<.01)\end{array}$ & & & & & & & \\
\hline $\begin{array}{l}\text { Courts cannot be used to } \\
\text { enforce contracts }\end{array}$ & $\begin{array}{c}0.1 \\
(1117,<.01)\end{array}$ & $\begin{array}{c}0.11 \\
(1117,<.01)\end{array}$ & $\begin{array}{c}0.22 \\
(1163,<.01)\end{array}$ & $\begin{array}{c}0.15 \\
(1099,<.01)\end{array}$ & & & & & & \\
\hline $\begin{array}{l}\text { Tax payments to government } \\
\text { as a \% of sales for firms in } \\
\text { industry }\end{array}$ & $\begin{array}{c}0.24 \\
(996,<.01)\end{array}$ & $\begin{array}{c}0.24 \\
(1007,<.01)\end{array}$ & $\begin{array}{c}0.31 \\
(1042,<.01)\end{array}$ & $\begin{array}{c}0.29 \\
(981,<.01)\end{array}$ & $\begin{array}{c}0.11 \\
(1130,<.01)\end{array}$ & & & & & \\
\hline $\begin{array}{l}\text { Firms make unofficial } \\
\text { payments for ongoing } \\
\text { registration }\end{array}$ & $\begin{array}{c}0.29 \\
(775,<.01)\end{array}$ & $\begin{array}{c}0.27 \\
(783,<.01)\end{array}$ & $\begin{array}{c}0.36 \\
(789,<.01)\end{array}$ & $\begin{array}{c}0.38 \\
(769,<.01)\end{array}$ & $\begin{array}{c}0.06 \\
(805, .09)\end{array}$ & $\begin{array}{c}0.19 \\
(756,<.01)\end{array}$ & & & & \\
\hline $\begin{array}{l}\text { Firms make unofficial } \\
\text { payments for fire/sanitary } \\
\text { inspection }\end{array}$ & $\begin{array}{c}0.33 \\
(840,<.01)\end{array}$ & $\begin{array}{c}0.32 \\
(843,<.01)\end{array}$ & $\begin{array}{c}0.29 \\
(857,<.01)\end{array}$ & $\begin{array}{c}0.39 \\
(830,<.01)\end{array}$ & $\begin{array}{c}0.03 \\
(881, .40)\end{array}$ & $\begin{array}{c}0.17 \\
(820,<.01)\end{array}$ & $\begin{array}{c}0.49 \\
(757,<.01)\end{array}$ & & & \\
\hline $\begin{array}{l}\text { Firms make unofficial } \\
\text { payments for tax inspection }\end{array}$ & $\begin{array}{c}0.36 \\
(816,<.01)\end{array}$ & $\begin{array}{c}0.34 \\
(818,<.01)\end{array}$ & $\begin{array}{c}0.32 \\
(828,<.01)\end{array}$ & $\begin{array}{c}0.43 \\
(806,<.01)\end{array}$ & $\begin{array}{c}0.01 \\
(843, .74)\end{array}$ & $\begin{array}{c}0.16 \\
(789,<.01)\end{array}$ & $\begin{array}{c}0.47 \\
(734,<.01)\end{array}$ & $\begin{array}{c}0.63 \\
(811,<.01)\end{array}$ & & \\
\hline Firm had loan before 1996 & $\begin{array}{c}0.15 \\
(1072,<.01)\end{array}$ & $\begin{array}{c}0.16 \\
(1082,<.01)\end{array}$ & $\begin{array}{c}0.26 \\
(1115,<.01)\end{array}$ & $\begin{array}{c}0.20 \\
(1055,<.01)\end{array}$ & $\begin{array}{c}0.06 \\
(1302, .02)\end{array}$ & $\begin{array}{c}0.15 \\
(1094,<.01)\end{array}$ & $\begin{array}{c}0.16 \\
(739,<.01)\end{array}$ & $\begin{array}{c}0.16 \\
(863, .01)\end{array}$ & $\begin{array}{c}0.08 \\
(828, .02)\end{array}$ & \\
\hline Firm has collateral & $\begin{array}{c}-0.05 \\
(997, .13)\end{array}$ & $\begin{array}{c}-0.03 \\
(1006, .28)\end{array}$ & $\begin{array}{c}-0.03 \\
(1040, .28)\end{array}$ & $\begin{array}{c}-0.05 \\
(980, .09)\end{array}$ & $\begin{array}{c}-0.05 \\
(1217, .08)\end{array}$ & $\begin{array}{c}-0.04 \\
(1018, .25)\end{array}$ & $\begin{array}{c}0.08 \\
(739, .03)\end{array}$ & $\begin{array}{c}0.03 \\
(805, .37)\end{array}$ & $\begin{array}{c}0.04 \\
(769, .29)\end{array}$ & $\begin{array}{c}0.30 \\
(1189,<.01)\end{array}$ \\
\hline
\end{tabular}

Notes: Correlations are for all five countries combined. The number of observations and significance level are in parentheses. 
Table 3

Use of Internal Finance

Number of firms

1996 profit after taxes, \% of annual sales

Estimated industry profit rate after taxes

Profit reinvestment, $\%$ of profits after taxes

Unreinvested profit, \% annual sales

Pola

$9.9 \%$

$11.1 \%$

$5.7 \%$

$10.0 \%$

$52.6 \%$

$42.3 \%$

$3.6 \%$

$2.4 \%$

$-0.2 \%$

$-1.1 \%$

1994-1996
$2.1 \%$

$9.9 \%$
238

Estimated industry profit rate after taxes

Profit reinvestment, \% of profits after taxes

Unreinvested profit, \% annual sales

SPINOFFS

Number of firms

1996 profit after taxes, \% of annual sales

Estimated industry profit rate after taxes

Profit reinvestment, $\%$ of profits after taxes

Unreinvested profit, \% annual sales
$10.5 \%$

$11.3 \%$

237

$53.6 \%$

$4.8 \%$

66

$7.7 \%$

$10.1 \%$

$49.0 \%$

$5.0 \%$
$6.0 \%$

$9.8 \%$

$44.8 \%$

$3.7 \%$

70

40

123

183

$13.4 \%$

$13.8 \%$

$20.8 \%$

$18.3 \%$

$19.0 \%$

$14.9 \%$

$54.2 \%$

$5.8 \%$

$12.2 \%$

$12.9 \%$

$29.4 \%$

$4.6 \%$

$9.6 \%$

$20.3 \%$

$17.7 \%$

$10.6 \%$

$10.5 \%$

$17.1 \%$

$14.0 \%$

$2.5 \%$

$39.4 \%$

$29.6 \%$

$3.5 \%$

$5.0 \%$

$11.2 \%$

$12.1 \%$

Profit reinvestment as a percent of profits excludes firms with zero or negative profits. In order to make the data more comparable to the external finance data shown in Table 4, we assume that firms with negative or zero profits reinvest zero percent of sales and have unreinvested profits of zero percent of sales. Profit reinvestment as a percent of annual sales is calculated by multiplying profits as a percent of sales by profit reinvestment as a percent of profits. Unreinvested profits as a percent of sales is calculated as profits as a percent of sales times one minus profit reinvestment as a percent of profits. See Appendix B for more detail on the calculations. 
Table 4

Sources of External Finance

Number of firms

Percent of firms with bank loans at start-up

Percent of firms with bank loans ever

Percent of firms with bank loans in 1996

Percent of firms with collateral

at the time of interview

Average 1996 loan, percent of annual sales

--all firms (no loan=0\%)

--firms with loans

Accounts payable, percent of annual sales

$$
\begin{aligned}
& \text {--all firms } \\
& \text {--firms with } 1996 \text { loans }
\end{aligned}
$$

\section{STARTUPS}

Number of firms

$2.5 \%$

\section{$3.4 \%$}

$4.2 \%$

Percent of firms with bank loans

$$
\begin{aligned}
& \text {--ever } \\
& \text {--in } 1996
\end{aligned}
$$

$72.2 \%$

$50.6 \%$

$42.4 \%$

$22.7 \%$

$2.5 \%$

$2.0 \%$

$2.5 \%$

$3.2 \%$

66

70

40

123

183

Percent of firms with bank loans

$$
\begin{aligned}
& \text {--ever } \\
& \text {--in } 1996
\end{aligned}
$$

$1.7 \%$

$7.3 \%$

NA

NA

281

$46.6 \%$

$20.8 \%$

$1.7 \%$

NA

$0.1 \%$

$0.9 \%$

Average 1996 loan, \% of annual sales (no loan=0\%)

Accounts payable, percent of annual sales
$62.1 \%$

$42.4 \%$

$80.0 \%$

$44.3 \%$

$1.5 \%$

$4.4 \%$

$3.2 \% \quad 4.0 \%$

$3.2 \% \quad 4.0 \%$

$72.5 \%$

$89.4 \%$

$78.5 \%$

$47.5 \%$

$21.5 \%$

$14.6 \%$

$2.2 \%$

$2.8 \%$

$0.6 \%$

NA

$0.1 \%$

$0.7 \%$

For details of variable definitions, see Section 2 of the text. 
Table 5

Reinvestment Rates

Firms with and without Loans

\begin{tabular}{|c|c|c|c|}
\hline & & $\begin{array}{l}\text { Firms with } \\
\text { loans in } 1996\end{array}$ & $\begin{array}{l}\text { Firms without } \\
\text { loans in } 1996\end{array}$ \\
\hline \multirow{4}{*}{$\begin{array}{l}\text { Reinvestment } \\
\text { rates, percent of } \\
\text { after-tax profits }\end{array}$} & $0-25 \%$ & $26.0 \%$ & $33.0 \%$ \\
\hline & $26-49 \%$ & $21.0 \%$ & $31.5 \%$ \\
\hline & $50-75 \%$ & $21.3 \%$ & $18.2 \%$ \\
\hline & $76-100 \%$ & $31.7 \%$ & $17.4 \%$ \\
\hline
\end{tabular}


Table 6

Ordered Probits for Reinvestment Rate in 1996

\begin{tabular}{|c|c|c|c|c|c|c|c|c|c|}
\hline & \multicolumn{6}{|c|}{ All Five Countries } & \multirow{2}{*}{$\frac{\begin{array}{c}\text { Poland, Slovakia } \\
\text { and Romania only }\end{array}}{(7)}$} & \multirow{2}{*}{$\begin{array}{l}\begin{array}{c}\text { Russia and Ukraine } \\
\text { only }\end{array} \\
(8)\end{array}$} & \multirow[b]{2}{*}{$\begin{array}{c}\text { All Five Countries } \\
(9) \\
\begin{array}{c}\text { Startups with loan } \\
\text { variables }\end{array}\end{array}$} \\
\hline & $\begin{array}{l}\text { (1) } \\
\text { All countries and } \\
\text { all firms, without } \\
\text { country and } \\
\text { industry controls }\end{array}$ & $\begin{array}{c}\text { (2) } \\
\text { All countries and } \\
\text { all firms, without } \\
\text { country controls }\end{array}$ & (3) & (4) & (5) & $\begin{array}{c}(6) \\
\text { With } 4 \text { element } \\
\text { insecurity of } \\
\text { property rights } \\
\text { index (startups } \\
\text { only) }\end{array}$ & & & \\
\hline Index for perceived insecurity of property rights & $\begin{array}{l}-0.17 \\
(5.51)\end{array}$ & $\begin{array}{l}-0.12 \\
(3.39)\end{array}$ & $\begin{array}{l}-0.12 \\
(1.97)\end{array}$ & $\begin{array}{l}-0.18 \\
(2.83)\end{array}$ & $\begin{array}{c}-0.0003 \\
(0.01)\end{array}$ & & $\begin{array}{l}-0.18 \\
(2.87)\end{array}$ & & $\begin{array}{l}-0.17 \\
(2.88)\end{array}$ \\
\hline Dummy for believing courts ineffective & & $\begin{array}{l}-0.18 \\
(2.01)\end{array}$ & $\begin{array}{l}-0.18 \\
(1.85)\end{array}$ & $\begin{array}{l}-0.15 \\
(1.31)\end{array}$ & $\begin{array}{l}-0.11 \\
(0.47)\end{array}$ & & $\begin{array}{l}-0.16 \\
(1.32)\end{array}$ & $\begin{array}{l}-0.45 \\
(1.95)\end{array}$ & $\begin{array}{l}-0.23 \\
(1.85)\end{array}$ \\
\hline $\begin{array}{l}\text { Index for perceived insecurity of property rights } \\
\text { including courts ( } 4 \text { elements index) }\end{array}$ & & & & & & $\begin{array}{l}-0.17 \\
(2.93)\end{array}$ & & & \\
\hline Estimated industry profit rate & & $\begin{array}{l}0.005 \\
(1.13)\end{array}$ & $\begin{array}{l}0.004 \\
(0.91)\end{array}$ & $\begin{array}{c}0.01 \\
(1.80)\end{array}$ & $\begin{array}{l}-0.02 \\
(0.97)\end{array}$ & $\begin{array}{c}0.01 \\
(1.81)\end{array}$ & $\begin{array}{c}0.01 \\
(1.86)\end{array}$ & $\begin{array}{l}-0.07 \\
(1.55)\end{array}$ & $\begin{array}{c}0.01 \\
(1.90)\end{array}$ \\
\hline Log of firm age & & $\begin{array}{l}-0.25 \\
(3.34)\end{array}$ & $\begin{array}{l}-0.30 \\
(3.73)\end{array}$ & $\begin{array}{l}-0.25 \\
(2.35)\end{array}$ & $\begin{array}{l}-0.77 \\
(3.51)\end{array}$ & $\begin{array}{l}-0.25 \\
(2.36)\end{array}$ & $\begin{array}{l}-0.25 \\
(2.40)\end{array}$ & $\begin{array}{l}-0.35 \\
(1.22)\end{array}$ & $\begin{array}{l}-0.33 \\
(2.69)\end{array}$ \\
\hline Dummy for being a startup & & $\begin{array}{c}0.30 \\
(2.80)\end{array}$ & $\begin{array}{c}0.35 \\
(2.73)\end{array}$ & & & & & $\begin{array}{l}-0.04 \\
(0.15)\end{array}$ & \\
\hline Tax payments as a percent of sales & & $\begin{array}{l}-0.01 \\
(1.69)\end{array}$ & $\begin{array}{l}-0.01 \\
(1.68)\end{array}$ & $\begin{array}{l}-0.004 \\
(0.92)\end{array}$ & $\begin{array}{l}-0.02 \\
(1.50)\end{array}$ & $\begin{array}{c}-0.004 \\
(0.93)\end{array}$ & $\begin{array}{c}-0.003 \\
(0.86)\end{array}$ & & $\begin{array}{c}-0.002 \\
(0.43)\end{array}$ \\
\hline Dummy for collateral to offer bank & & & & & & & & & $\begin{array}{l}-0.11 \\
(0.64)\end{array}$ \\
\hline Dummy for obtaining loan prior to 1996 & & & & & & & & & $\begin{array}{l}0.14 \\
(1.57)\end{array}$ \\
\hline Industry controls & No & Yes & Yes & Yes & Yes & Yes & Yes & Yes & Yes \\
\hline Country controls & No & No & Yes & Yes & Yes & Yes & Yes & Yes & Yes \\
\hline $\begin{array}{l}\text { Manager charactericstics } \\
\text { included in regression }\end{array}$ & No & No & Yes & Yes & Yes & Yes & Yes & Yes & Yes \\
\hline Number of observations & 815 & 815 & 815 & 619 & 196 & 619 & 574 & 116 & 559 \\
\hline Chi-square & 30.3 & 236.2 & 570.4 & 722.9 & 28.3 & 314.6 & 549.2 & 98.8 & 263.6 \\
\hline Probability & $<0.001$ & $<0.001$ & $<0.001$ & $<0.001$ & 0.005 & $<0.001$ & $<0.001$ & $<0.001$ & $<0.001$ \\
\hline
\end{tabular}

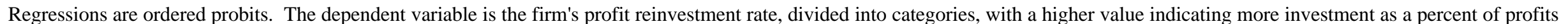

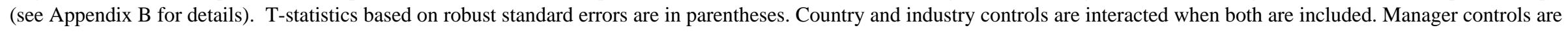

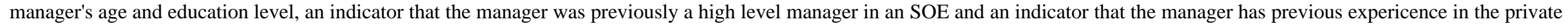
sector. 
Table 7

Predicted Profit Reinvestment Rate From the Ordered Probit Results in Table 6, Column 6

Profit Reinvestment rate

$$
\begin{array}{r}
0 \% \\
1-10 \% \\
11-25 \% \\
26-49 \% \\
50-75 \% \\
76-100 \%
\end{array}
$$

Weighted Investment rate

All Firms
$3.3 \%$
$13.7 \%$
$10.9 \%$
$20.2 \%$
$21.0 \%$
$30.8 \%$

$49.9 \%$
Most Secure ----- Insecurity of Property Rights Index ---- Least Secure

\begin{tabular}{rrrrr}
0 & 1 & 2 & 3 & 4 \\
\hline $1.9 \%$ & $3.2 \%$ & $4.4 \%$ & $6.5 \%$ & $9.2 \%$ \\
$10.4 \%$ & $13.6 \%$ & $16.6 \%$ & $21.0 \%$ & $25.0 \%$ \\
$9.5 \%$ & $11.1 \%$ & $12.4 \%$ & $14.0 \%$ & $14.9 \%$ \\
$19.2 \%$ & $20.6 \%$ & $21.3 \%$ & $21.8 \%$ & $21.3 \%$ \\
$22.0 \%$ & $21.4 \%$ & $20.3 \%$ & $18.4 \%$ & $16.1 \%$ \\
$36.9 \%$ & $30.2 \%$ & $25.0 \%$ & $18.3 \%$ & $13.5 \%$ \\
& & & & \\
$55.1 \%$ & $49.8 \%$ & $45.3 \%$ & $39.0 \%$ & $33.5 \%$
\end{tabular}

We calculate the probability of being in each investment category conditional on different values of the property rights index. We use the regression reported in Column 6 of Table 6, utilizing the four-element security index (i.e., including belief in the effectiveness of the courts). The last row of Table 7 shows the weighted average reinvestment rate for each value of the index, using the midpoint of each reinvestment category 
Table 8

Ordered Probits for Reinvestment Rate in 1996

All Five Countries

Startups only Startups only Startups only Startups only Startups only Startups only

$\begin{array}{llllll}(1) & (2) & (3) & \text { (4) } & \text { (5) } & \text { (6) }\end{array}$

\section{Dummy Variables for:}

Firms make extralegal

payments for services

Firms make extralegal

payments for licenses

Firms make payments

for protection

Firms make unofficial

payments--ongoing registration

Firms make unofficial

payments--fire and sanitary inspections

$-0.42$

(4.33)

$-0.11$

$(0.84)$

$-0.34$

(1.60)

$-0.40$

(3.04)

Firms make unofficial

payments--tax inspection

(2.45)

$\begin{array}{cc}\begin{array}{c}\text { Industry/ } \\ \text { country } \\ \text { Yes }\end{array} & \begin{array}{c}\text { Industry/ } \\ \text { country } \\ \text { Yes }\end{array} \\ 538 & 529 \\ 470.2 & 169.1 \\ <.001 & <.001\end{array}$

Courts cannot be used

$-0.16$

$-0.14$

(1.39)

(1.20)

$-0.13$

(1.13)

$-0.21$

(1.65)

to enforce contracts

$\begin{array}{cc}\begin{array}{c}\text { Industry/ } \\ \text { country } \\ \text { Yes }\end{array} & \begin{array}{c}\text { Industry/ } \\ \text { country } \\ \text { Yes }\end{array} \\ 619 & 619 \\ 428.4 & 339.8 \\ <.001 & <.001\end{array}$

Industry/
country
Yes

619
235.2
$<.001$

Industry/
country
Yes

499
512.3
$<.001$

(1.76)

Controls included

Manager charactericstics

Number of Observations

Chi-square

$<.001$
$-0.20$

(1.63)

$-0.14$

(1.21)

$<.001$

All regressions are ordered probits. The dependent variable is the level of investment, divided into categories, with a higher value indicating more investment as a percent of profits (see Appendix B for details). All regressions also include the entrepreneur's estimate of the industry profit rate and the age of the firm. T-statistics based on robust standard errors are in parentheses. 
Appendix Table 1

\section{Basic Characteristics of Spinoff and Start Up firms in Our Sample}

Poland Slovakia Romania Ukraine

\begin{tabular}{|c|c|c|c|c|c|c|c|c|c|c|}
\hline & Spinoffs & Startups & Spinoffs & Startups & Spinoffs & Startups & Spinoffs & Startups & Spinoffs & Startups \\
\hline Number of firms & 66 & 237 & 70 & 238 & 40 & 281 & 132 & 123 & 183 & 82 \\
\hline \multicolumn{11}{|l|}{ Year Founded } \\
\hline before 1990 & $13.6 \%$ & $40.9 \%$ & $7.1 \%$ & $6.3 \%$ & $0.0 \%$ & $1.1 \%$ & $6.8 \%$ & $5.7 \%$ & $17.5 \%$ & $6.1 \%$ \\
\hline 1990 & $4.5 \%$ & $12.2 \%$ & $1.4 \%$ & $10.5 \%$ & $25.0 \%$ & $5.3 \%$ & $12.9 \%$ & $11.4 \%$ & $18.8 \%$ & $12.3 \%$ \\
\hline 1991 & $18.2 \%$ & $8.4 \%$ & $17.1 \%$ & $14.7 \%$ & $37.5 \%$ & $16.7 \%$ & $21.2 \%$ & $18.7 \%$ & $13.7 \%$ & $12.2 \%$ \\
\hline 1992 & $19.7 \%$ & $12.7 \%$ & $44.3 \%$ & $21.0 \%$ & $17.5 \%$ & $24.9 \%$ & $15.2 \%$ & $13.8 \%$ & $8.7 \%$ & $14.6 \%$ \\
\hline 1993 & $18.2 \%$ & $8.0 \%$ & $8.6 \%$ & $16.4 \%$ & $2.5 \%$ & $13.9 \%$ & $15.2 \%$ & $30.1 \%$ & $17.5 \%$ & $23.2 \%$ \\
\hline 1994 & $9.1 \%$ & $8.0 \%$ & $4.3 \%$ & $9.2 \%$ & $12.5 \%$ & $18.5 \%$ & $17.4 \%$ & $9.8 \%$ & $16.9 \%$ & $19.5 \%$ \\
\hline 1995 & $12.1 \%$ & $5.1 \%$ & $5.7 \%$ & $10.5 \%$ & $2.5 \%$ & $16.0 \%$ & $6.8 \%$ & $7.3 \%$ & $5.5 \%$ & $8.5 \%$ \\
\hline 1996 & $0.0 \%$ & $3.0 \%$ & $10.0 \%$ & $9.2 \%$ & $2.5 \%$ & $3.6 \%$ & $3.0 \%$ & $1.6 \%$ & $3.6 \%$ & $2.4 \%$ \\
\hline
\end{tabular}

Entrepreneur's previous work experience

\begin{tabular}{|c|c|c|c|c|c|c|c|c|c|c|}
\hline Private Sector & $21.2 \%$ & $39.2 \%$ & $22.9 \%$ & $29.8 \%$ & $0.0 \%$ & $9.6 \%$ & $11.4 \%$ & $31.7 \%$ & $1.1 \%$ & $36.6 \%$ \\
\hline \multicolumn{11}{|l|}{ Public Sector } \\
\hline as a manager & $44.3 \%$ & $32.0 \%$ & $36.4 \%$ & $22.4 \%$ & $47.5 \%$ & $26.8 \%$ & $65.9 \%$ & $43.0 \%$ & $68.7 \%$ & $36.7 \%$ \\
\hline as an engineer & $41.0 \%$ & $31.7 \%$ & $36.4 \%$ & $39.7 \%$ & $50.0 \%$ & $52.0 \%$ & $29.4 \%$ & $53.1 \%$ & $29.1 \%$ & $61.2 \%$ \\
\hline as a worker & $23.0 \%$ & $42.5 \%$ & $27.3 \%$ & $36.8 \%$ & $2.5 \%$ & $20.1 \%$ & $5.6 \%$ & $5.1 \%$ & $2.2 \%$ & $2.0 \%$ \\
\hline Years of schooling & 16.3 & 15.6 & 16.6 & 16.1 & 16.7 & 16.0 & 15.5 & 15.1 & 15.4 & 14.8 \\
\hline \multicolumn{11}{|c|}{ Number of employees } \\
\hline First year & 83 & 33.4 & 119.3 & 19.3 & 257.1 & 25.4 & 47.1 & 21.7 & 72.6 & 31.9 \\
\hline 1994 & 87.6 & 47.1 & 137.4 & 36.8 & 188.8 & 34 & 47.7 & 21.1 & 76.4 & 32.0 \\
\hline 1996 & 92.4 & 55.1 & 118.0 & 45.8 & 148.8 & 45.5 & 48.2 & 22.0 & 78.5 & 36.2 \\
\hline \multicolumn{11}{|l|}{ Sector } \\
\hline Metal parts & $34.9 \%$ & $25.7 \%$ & $22.9 \%$ & $26.9 \%$ & $25.0 \%$ & $28.1 \%$ & $12.2 \%$ & $11.4 \%$ & $20.3 \%$ & $14.6 \%$ \\
\hline Wood products & $3.0 \%$ & $6.8 \%$ & $8.6 \%$ & $9.7 \%$ & $15.0 \%$ & $11.0 \%$ & $2.3 \%$ & $2.4 \%$ & $6.0 \%$ & $2.4 \%$ \\
\hline Food products & $4.6 \%$ & $13.9 \%$ & $24.3 \%$ & $6.7 \%$ & $17.5 \%$ & $19.9 \%$ & $8.4 \%$ & $12.2 \%$ & $6.6 \%$ & $6.1 \%$ \\
\hline Footwear/clothing & $6.1 \%$ & $19.4 \%$ & $4.3 \%$ & $15.1 \%$ & $12.5 \%$ & $15.0 \%$ & $15.3 \%$ & $16.3 \%$ & $2.8 \%$ & $7.3 \%$ \\
\hline Const. Materials & $18.2 \%$ & $6.8 \%$ & $15.7 \%$ & $8.8 \%$ & $22.5 \%$ & $10.0 \%$ & $15.3 \%$ & $16.3 \%$ & $18.7 \%$ & $8.5 \%$ \\
\hline Chemicals & $12.1 \%$ & $9.3 \%$ & $4.3 \%$ & $9.2 \%$ & $2.5 \%$ & $8.5 \%$ & $8.4 \%$ & $3.3 \%$ & $11.5 \%$ & $4.9 \%$ \\
\hline Paper and pack. & $1.5 \%$ & $1.7 \%$ & $5.7 \%$ & $3.8 \%$ & $2.5 \%$ & $2.5 \%$ & $6.9 \%$ & $8.1 \%$ & $1.7 \%$ & $2.4 \%$ \\
\hline Handicrafts & $1.5 \%$ & $1.3 \%$ & $0.0 \%$ & $0.8 \%$ & $0.0 \%$ & $1.8 \%$ & $1.5 \%$ & $0.8 \%$ & $0.6 \%$ & $4.9 \%$ \\
\hline Elec. Machinery & $12.1 \%$ & $7.2 \%$ & $7.1 \%$ & $8.8 \%$ & $0.0 \%$ & $0.7 \%$ & $15.3 \%$ & $8.9 \%$ & $11.5 \%$ & $11.0 \%$ \\
\hline Other & $6.1 \%$ & $8.0 \%$ & $7.1 \%$ & $10.1 \%$ & $2.5 \%$ & $2.5 \%$ & $14.5 \%$ & $20.3 \%$ & $20.3 \%$ & $37.8 \%$ \\
\hline
\end{tabular}

